\title{
Northern Red Sea: Nucleation of an oceanic spreading center within a continental rift
}

\author{
James R. Cochran \\ Lamont-Doherty Earth Observatory of Columbia University, Palisades, New York 10964, USA (jr@@ldeo.columbia.edu)
}

[1] The northern Red Sea is an amagmatic continental rift in which an oceanic spreading center is beginning to develop. A new compilation of marine geophysical data permits delineation of the structure of the northern Red Sea and of the manner in which the transition from continental to oceanic extension is occurring in this rift. The margins of the northern Red Sea are formed by large, apparently active faults on the seaward edge of the narrow continental shelves. The morphology of the main trough is a series of terraces stepping down to an axial depression. The terraces are a subdued expression of the basement structure, which consists of a series of large rotated fault blocks. The axial depression is an often faultbounded axis of deep water that extends south from the Suez triple junction. The rift is segmented alongstrike by throughgoing accommodation zones spaced at $40-60 \mathrm{~km}$ intervals along the rift. In the main trough, accommodation zones truncate or offset rift-parallel bathymetric and gravity features. The axial depression consists of a series of discrete depressions offset from each other and separated by slightly shallower areas corresponding to accommodation zones. Within each segment, the axial depression deepens away from the accommodation zones toward a small deep, a few kilometers across and a few hundred meters deeper than the surrounding seafloor. A pair of small volcanoes is perched on top of the scarps bounding the axial depression on either side of the deep within each segment. The volcanoes are all normally magnetized and interpreted as very young. The crust is uniformly thin $(5-8.5 \mathrm{~km})$ throughout the main trough, implying extension evenly spread across the rift through much of its development. As extension recently became concentrated at the axis, melt began to be generated and is focused to a location within the segment where it ascends along faults bounding the axial depression to form the pair of volcanoes flanking the axis. A volcano is also found on the floor of the axial depression in one segment. This isolated volcano appears to be the first step in the development of the seafloor spreading cells that are observed in the central Red Sea. The individual cells then grow and coalesce to become a continuous spreading axis.

Components: 17,282 words, 24 figures.

Keywords: continental rifting; extensional tectonics; Red Sea; segmentation.

Index Terms: 3099 Marine Geology and Geophysics: General or miscellaneous; 8038 Structural Geology: Regional crustal structure; 8105 Tectonophysics: Continental margins: divergent (1212, 8124); 8109 Tectonophysics: Continental tectonics: extensional (0905).

Received 26 August 2004; Revised 3 January 2005; Accepted 26 January 2005; Published 8 March 2005.

Cochran, J. R. (2005), Northern Red Sea: Nucleation of an oceanic spreading center within a continental rift, Geochem. Geophys. Geosyst., 6, Q03006, doi:10.1029/2004GC000826.

\section{Introduction}

[2] The Red Sea is the closest active analog to the rifting and rupturing of continental lithosphere that has formed most "Atlantic-type" continental margins. Nearly all of the passive margins of the Indian, Atlantic and Arctic Oceans have been formed by nucleation of an oceanic spreading center within a continental rift after an extended 
period of rifting. The Red Sea has formed by the rupturing of Precambrian lithosphere beginning in the late Oligocene. Seafloor spreading began at about $5 \mathrm{Ma}$ in the southern Red Sea [Roeser, 1975] and the transition from continental to oceanic rifting is presently occurring in the central and northern Red Sea [Martinez and Cochran, 1988; Guennoc et al., 1990; Cochran et al., 1991].

[3] The fact that active late-stage continental rifting is occurring in the northern Red Sea with a transition along-strike to an active oceanic midocean ridge in the southern Red Sea allows the development of the rift and the processes shaping it during the transition from continental to oceanic rifting to be directly observed. At fossil passive margins, these processes need to be inferred from the crustal structure and sedimentary record remaining after the process is complete.

[4] The purpose of this paper is to utilize a new compilation and synthesis of geophysical data from the northern Red Sea to examine how a mid-ocean ridge-type spreading center develops within a continental rift. This study will focus on the northern Red Sea from $25^{\circ} \mathrm{N}$ to $28^{\circ} \mathrm{N}$ (Figure 1), where small cells of magmatic extension are just beginning to nucleate at the axis of what has been a nearly amagmatic rift.

\section{Geological Setting of the Red Sea Rift}

[5] The Red Sea occupies a $1900 \mathrm{~km}$ long riftbounded depression reaching from the Gulf of Suez to the Straits of Bab el Mandab (Figure 1), extending through the interior of the once contiguous Afro-Arabian craton. The Gulf of Suez, which extends an additional $300 \mathrm{~km}$ to the northwest, was a continuation of the Red Sea Rift until it was cut off in the mid Miocene by the development of the Dead Sea transform. Uplift and unroofing began nearly simultaneously along the entire Red Sea at $\sim 34 \mathrm{Ma}$ according to fission track data [Omar and Steckler, 1995]. However, there is no dated sedimentary evidence of significant uplift and erosion at this time [Bosworth et al., 1998]. The main phase of rifting began at $\sim 22 \mathrm{Ma}$ based on fission track data [Omar and Steckler, 1995] and at 23-27 Ma based on stratigraphic data [e.g., Bosworth and McClay, 2001; Hughes et al., 1991, 1999].

[6] Seafloor spreading in the Red Sea nucleated near $17^{\circ} \mathrm{N}$ at $\sim 5 \mathrm{Ma}$ and propagated both north and south from that location [Roeser, 1975; Courtillot,

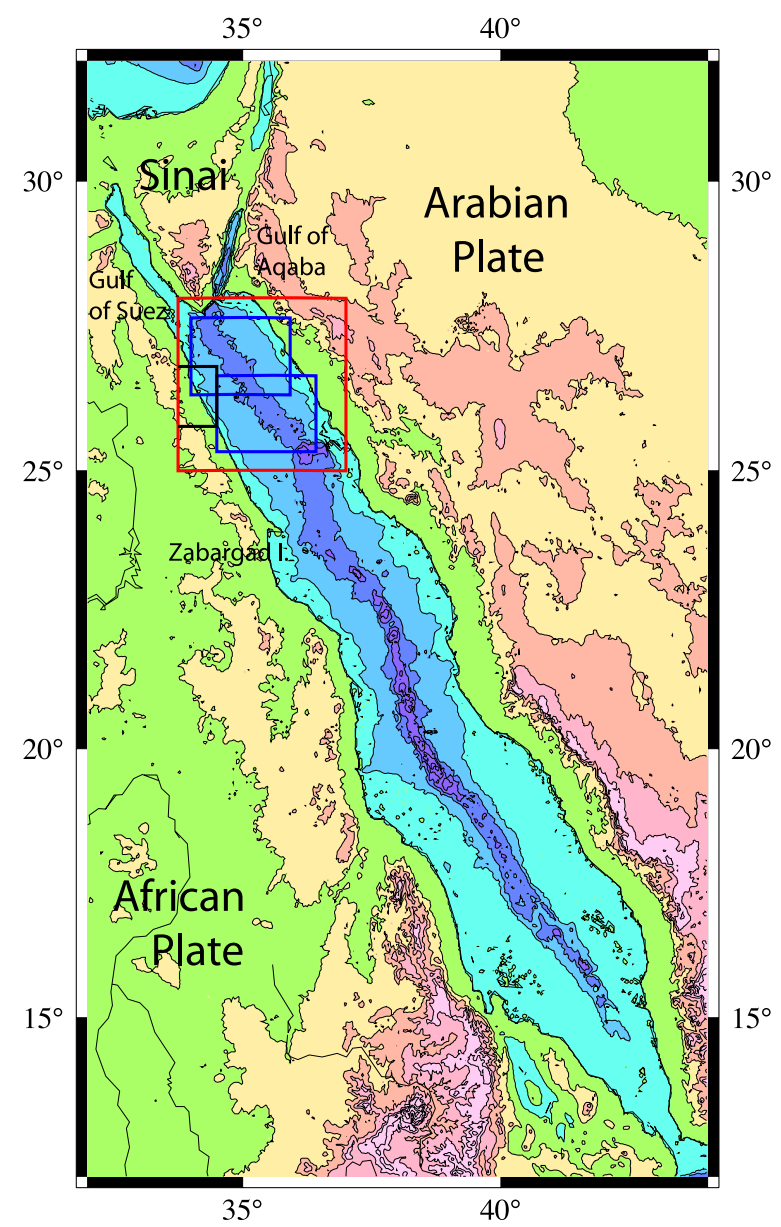

Figure 1. Location map of the Red Sea. The region shown in Figures $2 \mathrm{a}-2 \mathrm{c}, 3,4 \mathrm{a}, 4 \mathrm{~b}, 5,6$, and 8 is outlined in red. The regions shown in Figures 11a, 11b, $12 \mathrm{a}$, and $12 \mathrm{~b}$ are outlined in blue. The region shown in Figure 13 is outlined in black. Bathymetry and topography are contoured at $500 \mathrm{~m}$ intervals. Bathymetry is based on satellite altimetry measurements and is from the Smith and Sandwell [1997] grid.

1982; Cochran, 1983]. The spreading center becomes discontinuous north of $19.5^{\circ} \mathrm{N}$, passing into a transition zone made up of a series of discrete seafloor spreading cells or "deeps" [Pautot, 1983; Cochran, 1983; Bonatti, 1985; Bicknell et al., 1986] extending north to $\sim 23^{\circ} \mathrm{N}$. The northern $700 \mathrm{~km}$ of the Red Sea are in the latest stages of continental rifting [Pautot et al., 1986; Martinez and Cochran, 1988; Cochran et al., 1991]. Thus the transition from continental rifting through an established seafloor spreading axis is displayed along-strike in the Red Sea.

[7] Current total spreading rates determined from magnetic anomalies in the southern Red Sea reach a maximum of 15-16 mm/a [Roeser, 1975; Chu 


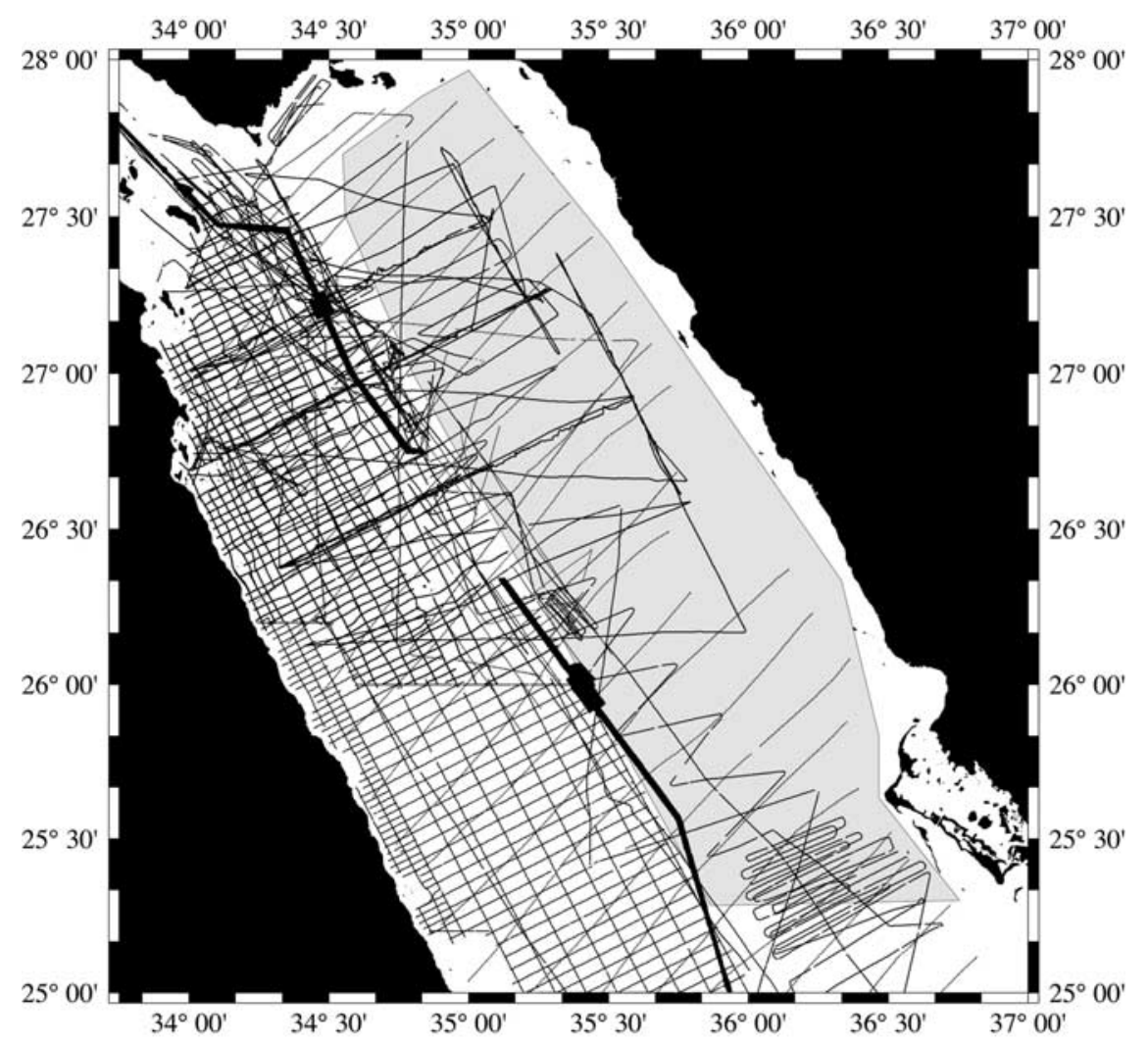

Figure 2a. Bathymetry database in the northern Red Sea. A dot is shown at the location of each bathymetry measurement. Data sources are discussed in the text. Shaded area marks extent of detailed Preussag Meerstechnik bathymetry maps that were used to supplement the digital data. There are a total of 275,493 digital shipboard measurements.

and Gordon, 1998]. Kinematic models predict total opening rates in the range of $7.5-9.5 \mathrm{~mm} / \mathrm{a}$ in the northernmost Red Sea [Joffe and Garfunkel, 1987; Jestin et al., 1994; Chu and Gordon, 1998]. Opening rates in the Red Sea are low by oceanic standards, although they are greater than generally observed in continental rifts. They are, however, comparable to rates observed in the earliest stages of spreading in the North Atlantic and Labrador Sea [Bown and White, 1994]. Current opening directions predicted by the kinematic models vary from $\mathrm{N} 45^{\circ} \mathrm{E}$ to $\mathrm{N} 52^{\circ} \mathrm{E}$ in the southern Red Sea and from $\mathrm{N} 30^{\circ} \mathrm{E}$ to $\mathrm{N} 37^{\circ} \mathrm{E}$ in the northernmost Red Sea. These opening directions are $\sim 10^{\circ}-30^{\circ}$ from orthogonal to the overall $\mathrm{N} 150^{\circ} \mathrm{E}$ trend of the rift.

[8] The onset of rifting in the Red Sea was preceded by massive basaltic volcanism in Ethiopia and southern Yemen that ${ }^{40} \mathrm{Ar} /{ }^{39} \mathrm{Ar}$ dating shows to have occurred over a very short $(\sim 1.5 \mathrm{myr})$ time period at $\sim 30$ Ma [Hofmann et al., 1997; Coulie et al., 2003]. This flood volcanism has been attributed to impingement of the Afar plume head on the lithosphere [Richards et al., 1989]. An episode of dike intrusion [Blank, 1977] dated at 24-21 Ma on the basis of K-Ar and ${ }^{40} \mathrm{Ar} /{ }^{39} \mathrm{Ar}$ data is recorded along the entire length of the Red Sea on the Arabian margin [Bartov et al., 1980; Eyal et al., 1981; Sebai et al., 1991; Feraud et al., 1991]. This episode was more intense in the southern Red Sea and was there accompanied in places by intrusion of plutonic bodies of granitic to gabbroic composition [Pallister, 1987; Davison et al., 1994; Sebai et al., 1991]. Episodic volcanism has continued to the present in Afar and in southern Yemen [e.g., Zumbo et al., 1995a, 1995b; Coulie et al., 2003], as well as in the "Harrats", large regions of basaltic flows on the Arabian plate outside of the Red Sea rift [Coleman et al., 1975, 1983; Sebai et al., 1991].

[9] After this early Miocene diking event, there has been little significant volcanic activity within the Red Sea rift, particularly in the northern Red Sea, prior to the in-progress transition to seafloor spreading [Coleman et al., 1983; Coleman, 1984; Coleman and McGuire, 1988; Sebai et al., 1991]. In the Gulf of Suez and along the Egyptian Red 


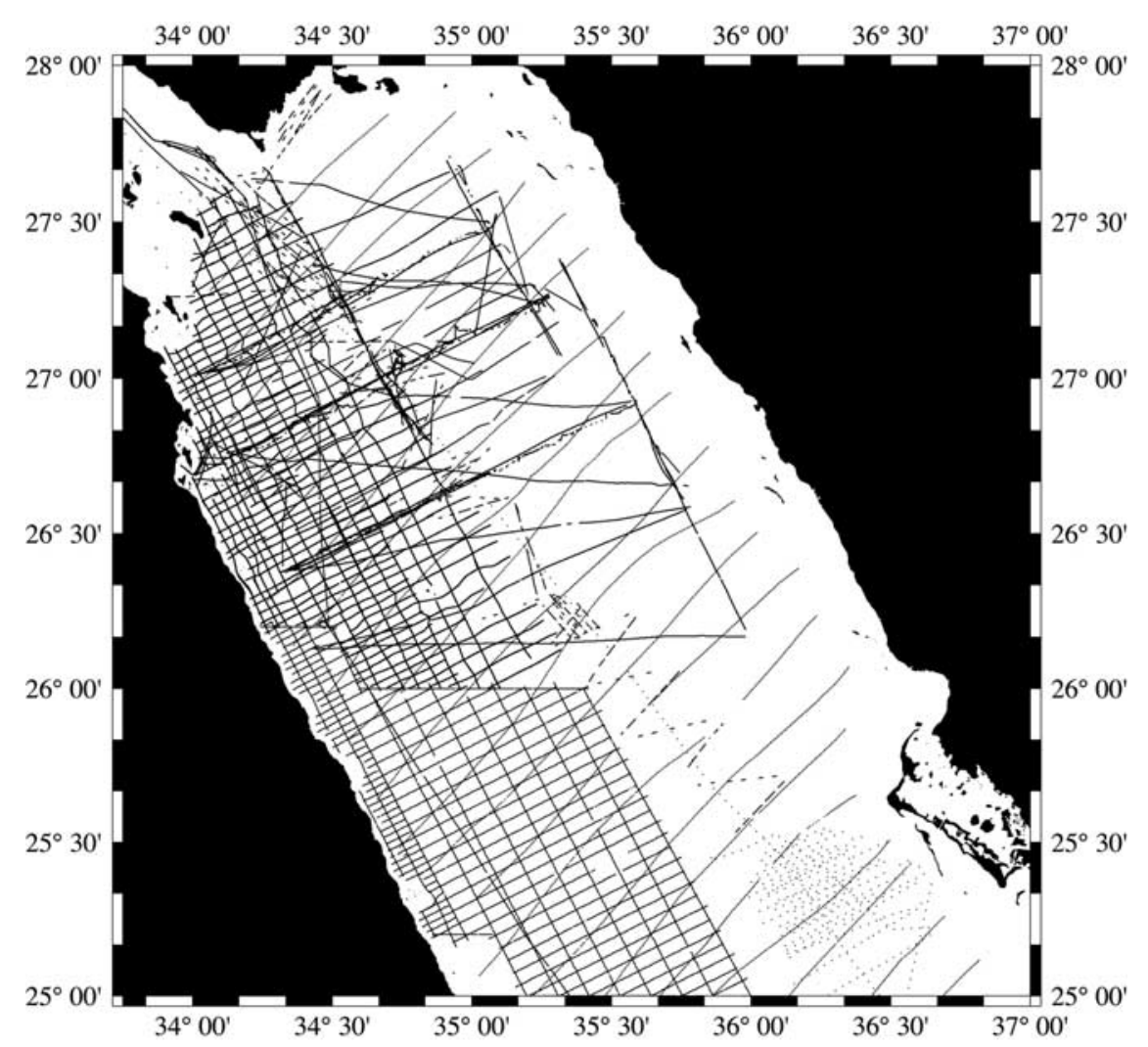

Figure 2b. Gravity database in the northern Red Sea. A dot is shown at the location of each gravity measurement. Data sources are discussed in the text. There are a total of 170,707 digital shipboard measurements.

Sea coast, minor basaltic flows and dikes are found in some places in the lowermost syn-rift red bed unit, but not in the overlying syn-rift section [Plaziat et al., 1998b; Bosworth and McClay, 2001]. Extension in the central and northern Red Sea rift appears to have been primarily accommodated mechanically by rotation of large crustal blocks [Colletta et al., 1988; Martinez and Cochran, 1988; Cochran et al., 1991; Bosworth, 1994; Bosworth et al., 1998].

[10] The morphology of the Red Sea consists of narrow marginal shelves and coastal plains and a broad "main trough" with depths of 400-1200 m. In the southern Red Sea (south of about $20^{\circ} \mathrm{N}$ on the Arabian side and $17^{\circ} \mathrm{N}$ on the African side), the main trough is filled in by coral reefs. From $15^{\circ} \mathrm{N}$ to $19.5^{\circ} \mathrm{N}$, the sea is bisected by an "axial trough" less than $60 \mathrm{~km}$ wide with depths of more than $2000 \mathrm{~m}$ occupied by a mid-ocean ridge spreading center [Roeser, 1975; Cochran, 1983; Miller et al., 1985; Garfunkel et al., 1987]. The central Red Sea oceanic deeps also reach depths of greater than $2000 \mathrm{~m}$ and are floored by oceanic basalt [Bicknell et al., 1986]. However, they are separated by "intertrough zones" which are shallower, broader, and covered with highly faulted sediments including both the Miocene evaporites and post-Miocene pelagic sediments [Searle and Ross, 1975; Izzeldin, 1989].

[11] Atlantis II Deep, centered at $21^{\circ} 16.5^{\prime} \mathrm{N}$, $38^{\circ} 5^{\prime} \mathrm{E}$, has been the site of extensive investigations due largely to of the presence of metaliferous sediments within the deep [e.g., Degens and Ross, 1969; Backer and Schoell, 1972; Zierenberg and Shanks, 1988]. Atlantis II Deep has also been the location of DSDP drilling (Holes 225-227) on Leg 23 [Whitmarsh et al., 1974] and has been mapped using swath mapping techniques [Pautot, 1983]. Basalt fragments have been recovered from Atlantis II Deep [Shipboard Scientific Party, 1974; Coleman et al., 1973] and from Hatiba Deep (located at $22^{\circ} \mathrm{N}$ ) [Chase, 1969]. Nereus Deep, at about $23^{\circ} 10^{\prime} \mathrm{N}$, is the farthest north of the oceanic deeps. Nereus Deep has also been partially mapped with SeaBeam [Pautot, 1983] and was the site of a magnetics and bathymetry deep-tow traverse [Bicknell et al., 1986]. These studies show a volcanic ridge down the center of Nereus Deep that appears to be a mid-ocean ridge-type spreading center. Magnetics data [Roeser, 1975; Bicknell et 


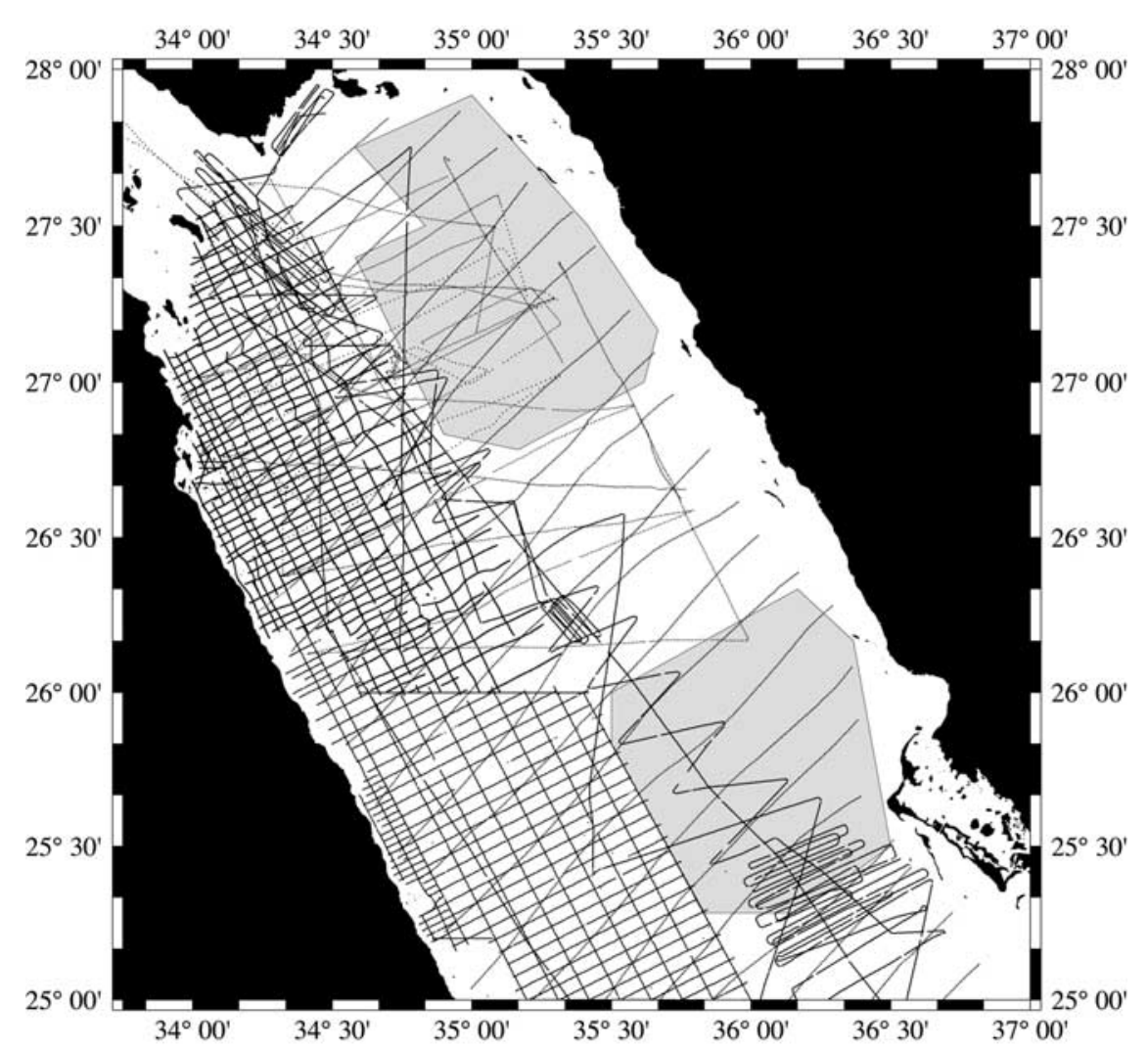

Figure 2c. Magnetics database in the northern Red Sea. A dot is shown at the location of each measurement. All data are total intensity measurements obtained from towed proton precession magnetometers. Data sources are discussed in the text. Shaded area marks extent of detailed Preussag Meerstechnik magnetics maps that were used to supplement the digital data. There are a total of 152,885 digital shipboard measurements.

al., 1986] imply that organized spreading at Nereus Deep has been occurring for $<780 \mathrm{kyr}$. The other deeps are less well known with an early 1970s single-beam sonar survey [Backer et al., 1975] still the primary data source.

[12] A series of "deeps" is also found in the northern Red Sea extending nearly to the intersection with the Dead Sea Transform [Backer and Schoell, 1972; Pautot, 1983; Martinez and Cochran, 1988]. These are, however, very different from the oceanic central Red Sea deeps. With the possible exception of the Mabahiss Deep pull-apart basin centered at $25^{\circ} 20^{\prime} \mathrm{N}, 36^{\circ} 10^{\prime} \mathrm{E}$, there is no evidence of oceanic crust in the northern Red Sea. The northern deeps are much shallower $\left(\sim 1300_{-}\right.$ $1500 \mathrm{~m}$ ) and smaller (a few $\mathrm{km}$ across) than the oceanic deeps. A small volcano is observed in Bannock Deep $\left(23^{\circ} 33^{\prime} \mathrm{N}\right)$ and in Shaban Deep $\left(26^{\circ} 14^{\prime} \mathrm{N}\right)$ [Bonatti et al., 1984; Pautot et al., 1984], but in general the deeps are sediment floored. Most of the northern Red Sea deeps are associated with large, normally magnetized, dipolar magnetic anomalies that imply the presence of recent, localized intrusions [Cochran et al., 1986]. These deeps have been interpreted as the first stages in the establishment of a magmatic spreading axis within the northern Red Sea by Martinez and Cochran [1988].

\section{Marine Geophysical Data in the Northern Red Sea}

[13] The location of data used for this study is shown in Figures $2 a-2 c$. There has been virtually no academic marine geological or geophysical fieldwork in the Red Sea since the late 1980s, and almost all of the available geophysical data from the Red Sea date from prior to 1990. As a result, the bathymetry data (Figure 2a) consist almost entirely of single-beam echo sounder data or narrow 24-beam "classic" SeaBeam swath data. The only wide swath-bathymetry data available is a single north-south transit line run by L'Atalante in 1992 utilizing a Simrad swath-mapping system.

[14] A primary component of the database is two systematic oil industry surveys of the Egyptian 

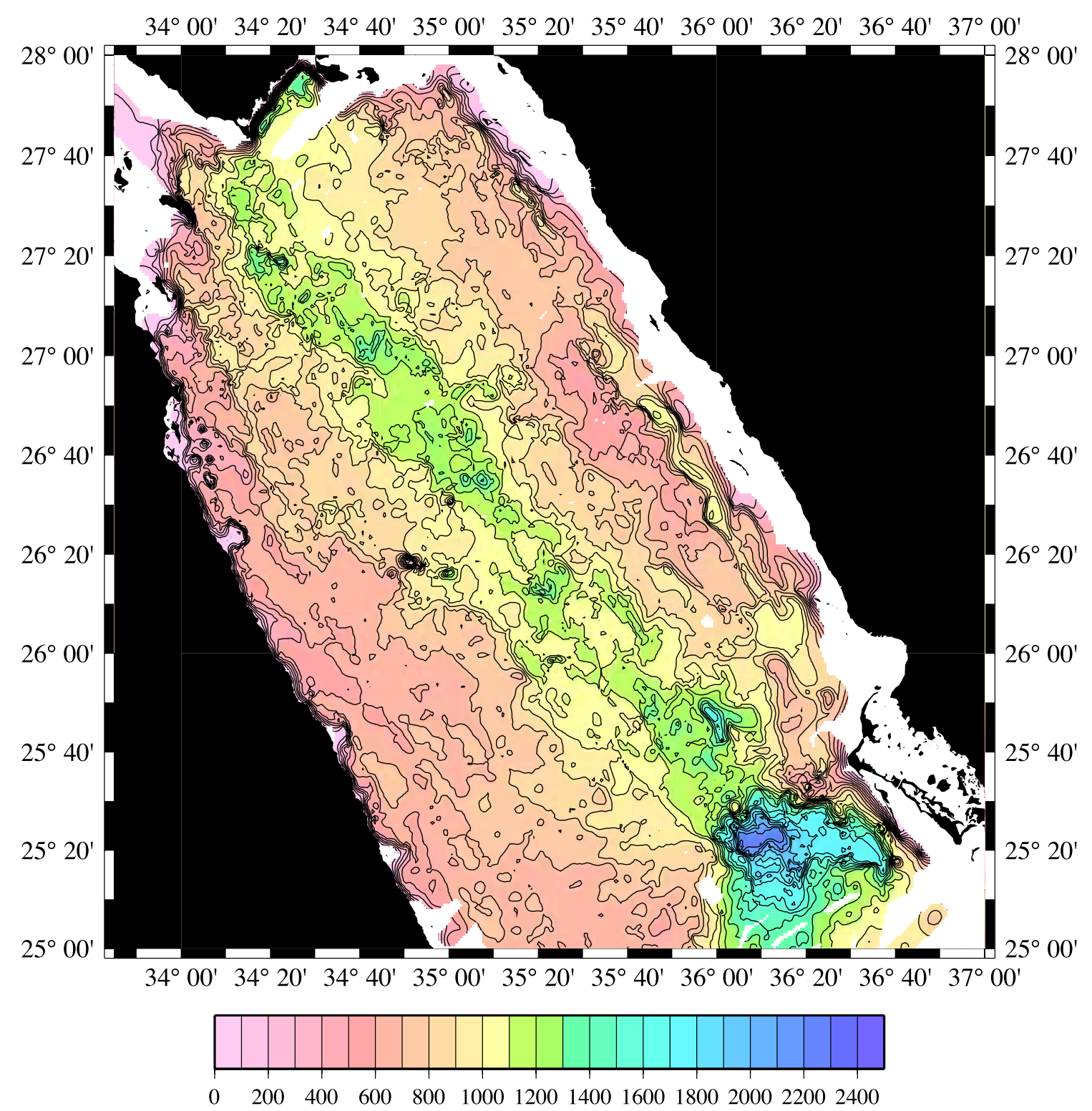

\section{Meters}

Figure 3. Bathymetry map of the northern Red Sea contoured at $100 \mathrm{~m}$ intervals. Data distribution is shown in Figure 2a.

portion of the northern Red Sea. Other significant data sources include R/V Robert D. Conrad cruise 2507 [Martinez and Cochran, 1988, 1989; Cochran and Martinez, 1988; Cochran et al., 1986, 1991], several cruises on N/O Jean Charcot carried out by IFREMER [Pautot, 1983; Pautot et al., 1984, 1986; Guennoc et al., 1988, 1990], bathymetry data collected by N/O Suroit during a seismic refraction experiment [Gaulier et al., 1988] and two British cruises on RRS Shackleton [Girdler and Southren, 1987] and RRS Discovery [Garfunkel et al., 1987].
[15] Additional bathymetry data are available from the NGDC database, mostly transit lines through the study area. However, the majority of this data showed large, erratic crossover errors with the data shown on Figure 2a that appear to be the result of navigational errors. It was not possible to reconcile most of this data with the remainder of the data set. As a result, data from very few of those cruises were used.

[16] Data is much sparser on the Arabian side of the sea. A systematic survey of that region was 


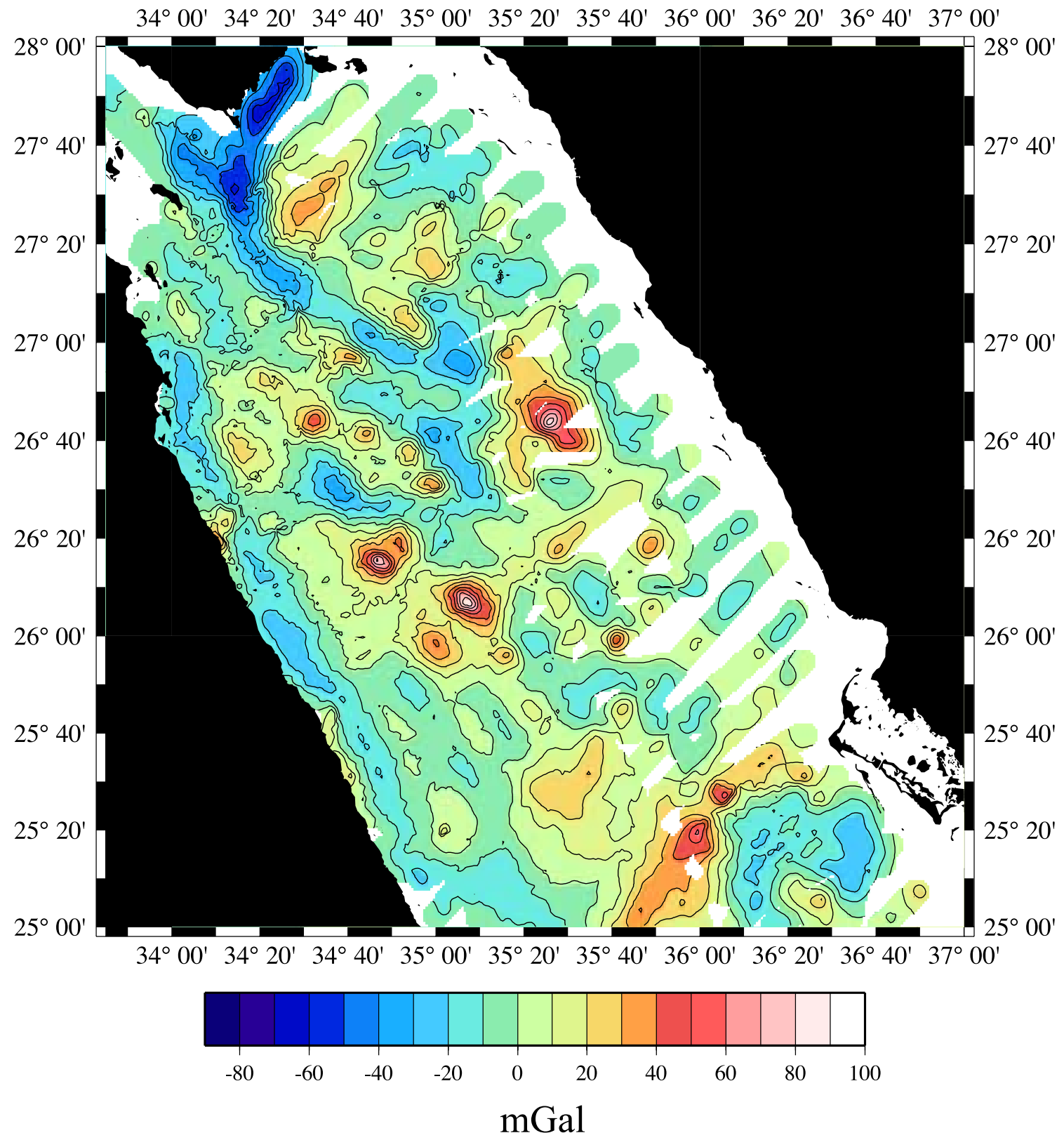

Figure 4a. Free-air gravity anomaly map of the northern Red Sea contoured at $10 \mathrm{mGal}$ intervals. Data distribution is shown in Figure $2 \mathrm{~b}$.

carried out by Preussag Meerstechnik [Richter et al., 1991]. Digital data from that survey are not available and may no longer exist (H. A. Roeser, personal communication, 2001). However, the German BGR provided detailed bathymetry and magnetic anomaly contour maps of portions of the survey (regions shaded in Figures $2 \mathrm{a}$ and $2 \mathrm{c}$ ). The maps were compared to available digital data. Where there was good agreement, the contours were digitized to use in producing data grids. Line spacing for the Preussag survey varied from 2 to $8 \mathrm{~km}$ and was densest in the areas where both bathymetry and magnetics data were collected (Figure 2c).

[17] The total number of digital shipboard measurements in the compilation amounts to 275,493 bathymetry, 170,707 gravity and 152,885 magnetics data points. Each of the data sets was gridded with a $1 \mathrm{~km}^{2}$ grid cell and fit with a smooth surface [Wessel and Smith, 1998; Smith and Wessel, 1990]. A bathymetric map of the northern Red Sea contoured at $100 \mathrm{~m}$ intervals is shown in Figure 3. Free-air and Bouguer gravity 


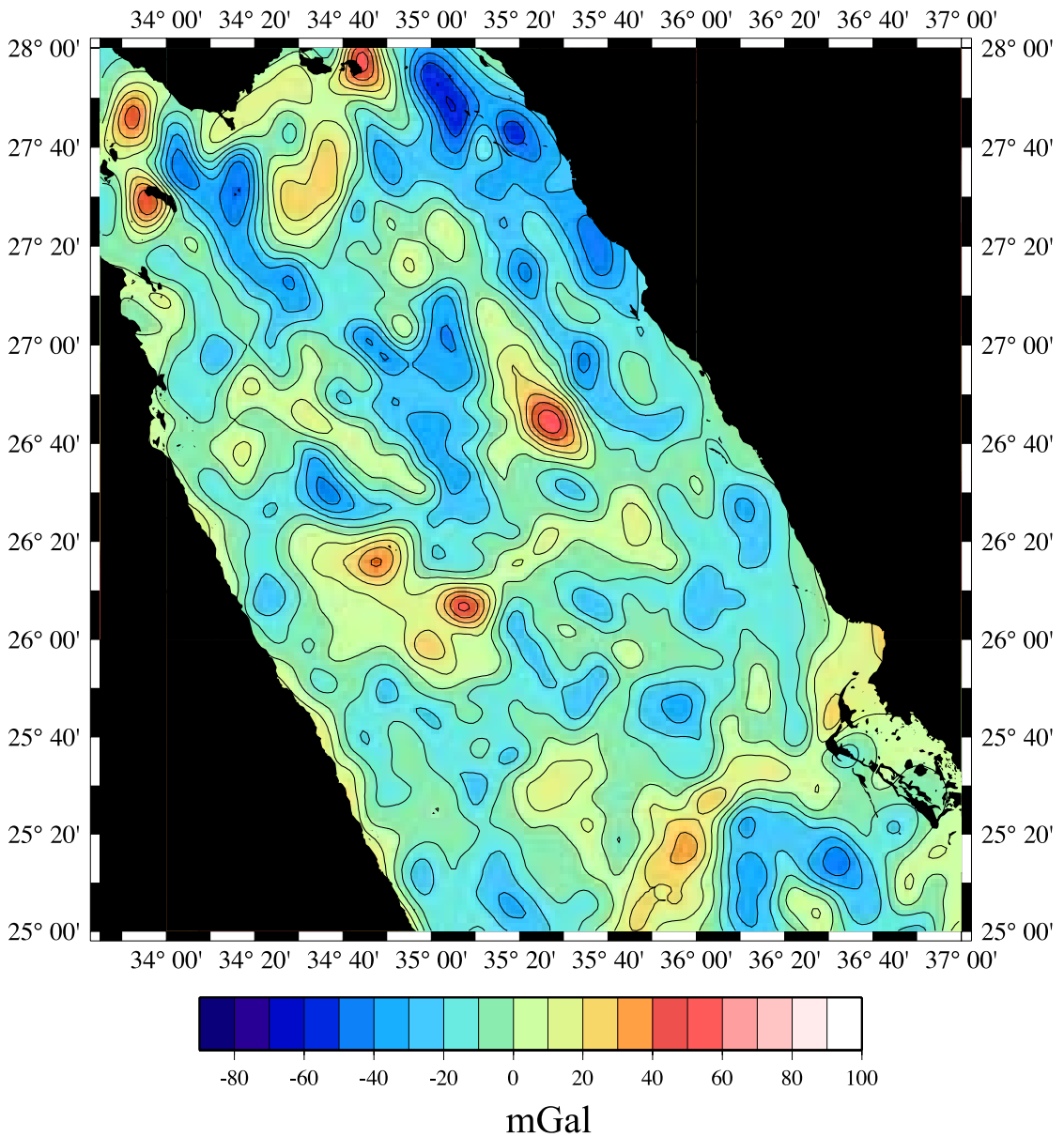

Figure 4b. Free-air gravity anomaly map of the northern Red Sea based on satellite altimetry data [Sandwell and Smith, 1997, 1999]. Contour interval is $10 \mathrm{mGal}$.

anomaly maps contoured at $10 \mathrm{mGal}$ and a total intensity magnetic anomaly map contoured at $50 \mathrm{nT}$ are shown in Figures 4a, 5, and 6.

[18] Gravity coverage on the eastern side of the Red Sea is somewhat sparse (Figure 2b). However, a gravity map (Figure 4b) prepared from satellite altimetry data [Sandwell and Smith, 1997, 1999] shows exactly the same pattern of anomalies as does the surface ship data (Figure 4a), although with less resolution. The agreement between the surface-ship and satellite data verifies the contouring of the surface ship data in the regions of sparser data.

\section{Rift Structure and Segmentation}

\subsection{Rift Structure and Morphology}

[19] The continental margins of the northern Red Sea are abrupt and faulted, with a narrow coastal plain and continental shelf. The seaward edge of the narrow, shallow shelves is marked by a scarp, with 400-500 $\mathrm{m}$ of relief along the African margin (Figures 3 and 7). On the Arabian side, a $5-10 \mathrm{~km}$ wide trough with water depths often exceeding $1000 \mathrm{~m}$ is located at the foot of the shelf-edge escarpment along most of the margin north of $25^{\circ} 50^{\prime} \mathrm{N}$. The trough is usually bounded on the seaward side by a 200-500 m high scarp (Figure 3) and appears to be a graben structure. A less-pronounced graben-like trough is observed along portions of the Egyptian margin, particularly to the south of $26^{\circ} 20^{\prime} \mathrm{N}$.

[20] Landward of the margin, rotated basement fault blocks are found $2-10 \mathrm{~km}$ from the coast where they form elongated hills and ridges with $300-500 \mathrm{~m}$ of relief. Additional, higher ridges are located further inland and in places, particularly on the Arabian side, a prominent rift-bounding escarpment is found. Mid-Miocene reef platforms 


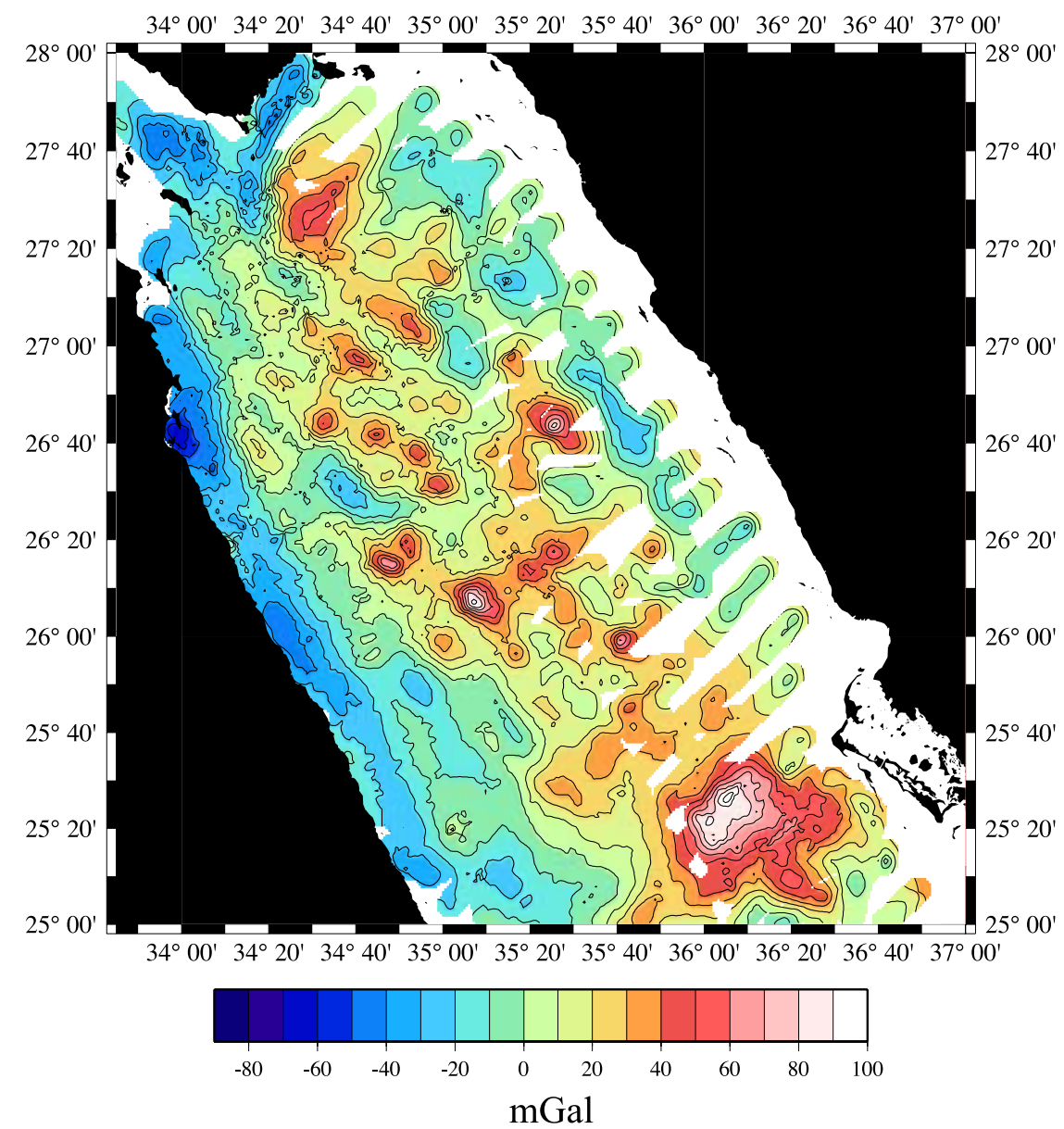

Figure 5. Bouguer gravity anomaly map of the northern Red Sea contoured at $10 \mathrm{mGal}$ intervals. A density of $2730 \mathrm{~kg} / \mathrm{m}^{3}$ (density contrast of $1700 \mathrm{~kg} / \mathrm{m}^{3}$ with seawater) was used in calculation for the Bouguer anomalies. Data distribution is shown in Figure $2 \mathrm{~b}$.

that are consistently at elevations of 200-300 m are found mantling the first basement fault block along much of the African margin [Bosworth et al., 1998]. Similar uplifted Mid-Miocene fringing reefs along the seaward edges of fault blocks are observed for at least $200 \mathrm{~km}$ along the Arabian margin [Purser and Hötzl, 1988]. These fault blocks are inactive and have been marked by emergence and nondeposition since the Late Miocene [Montentat et al., 1988].

[21] Seaward of the exposed basement fault blocks, the Red Sea coast to the south of the Aqaba transform is characterized by Mid Pleistocene reef terraces that have been uplifted by $20-50 \mathrm{~m}$ along both margins [Purser and Hötzl, 1988; Purser et al., 1990; Plaziat et al., 1998a; Bosworth et al., 1998]. This pattern of raised reefs traces a progressive narrowing of the actively extending rift, as fault blocks become inactive and are transferred to the uplifting rift shoulder. The well-developed graben at the base of the shelf-edge scarp on the Arabian margin suggests strongly that the fault forming that escarpment is presently active.

[22] Seaward of the shelf-edge scarps, the bathymetry steps down in a series of terraces to an axial depression at a depth of about 1100-1200 m. Figure 7 shows a bathymetry and gravity profile and an accompanying single-channel seismic reflection line across the Red Sea that crosses the axis near $27^{\circ} \mathrm{N}$ (location is shown in Figure 8). The terraced nature of the main trough is well displayed, as is a well-defined axial depression which, on this profile, is fault bounded. Free-air gravity anomaly highs are systematically located on the seaward edge of the terraces. Martinez and Cochran [1988] determined that possible density variations within the sedimentary section are insufficient to account for the observed gravity 

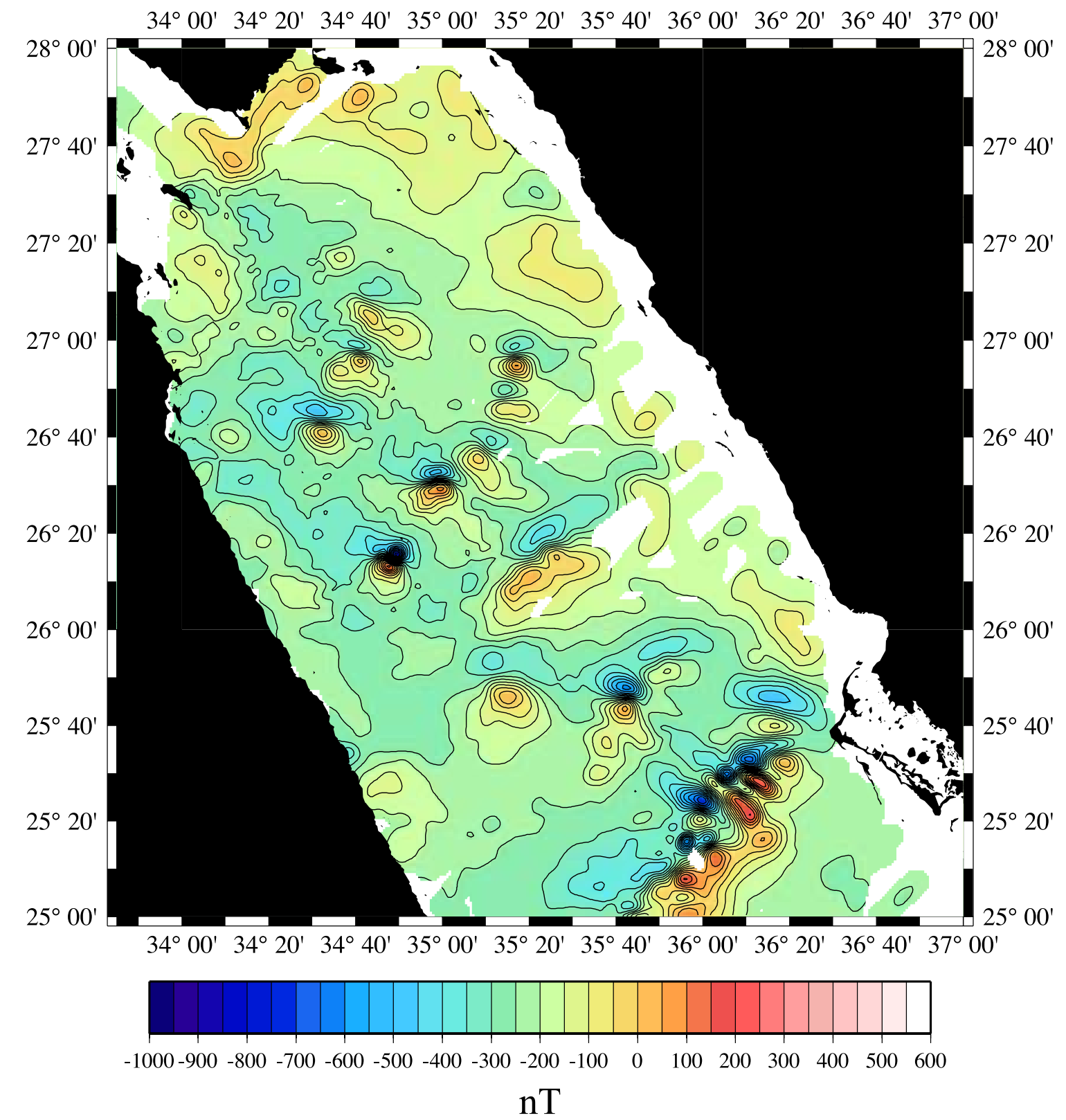

Figure 6. Total intensity magnetic anomaly map of the northern Red Sea contoured at $50 \mathrm{nT}$ intervals. Data distribution is shown in Figure 2c.

anomalies and that the anomalies must result reflect relief on crystalline basement. They interpreted the pattern of bathymetry and gravity anomalies as resulting from a series of large rotated crustal fault blocks whose presence is reflected in a muted manner by the bathymetric terraces.

[23] The profile shown in Figure 7 runs perpendicular to a series of rift-parallel expanding-spreadprofile (ESP) seismic lines [Gaulier et al., 1988]. The location at which the profile crosses each ESP line is noted. A synthetic cross section from Gaulier et al. [1988] in which they drew the basement structure to be consistent with the interpretation of Martinez and Cochran [1988] is also shown in Figure 7. Detailed quantitative analysis of this same gravity and bathymetry line by Cochran et al. [1991] suggests that there actually must be significantly more relief on the block-bounding faults. This implies that the fault blocks are more rotated than drawn in the sketch of Gaulier et al. [1988]. Also note the thin crust and relatively uniform depth to the Moho in Figure 7. Gaulier 


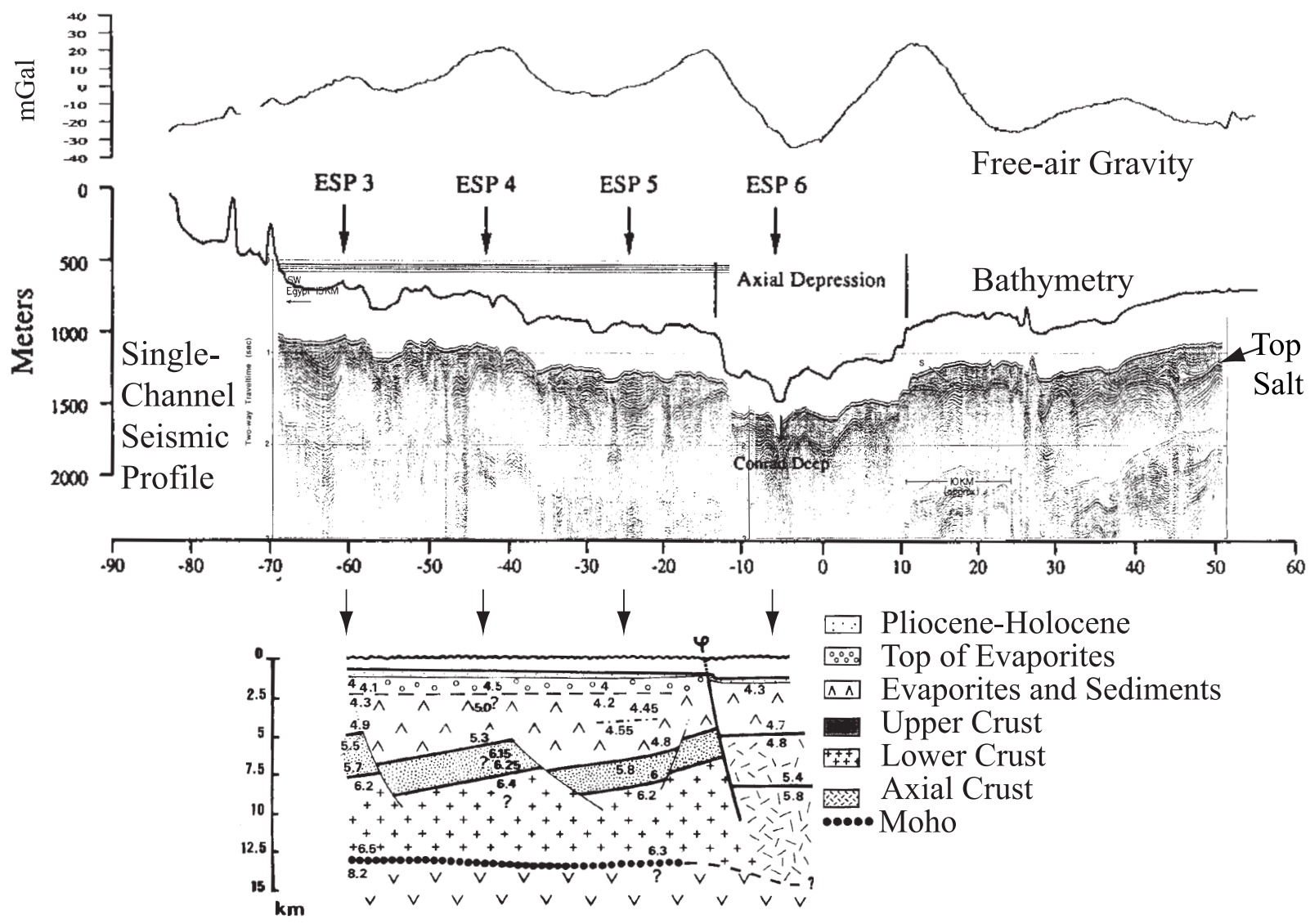

Figure 7. (top) Seismic reflection, bathymetry, and free-air gravity profiles across the Red Sea near $27^{\circ} \mathrm{N}$ (location shown in Figure 8). Profile is projected along $\mathrm{N} 60^{\circ} \mathrm{E}$ with west to the left. The profile crosses the axial depression at the location of Conrad Deep. Note terraced nature of the Red Sea and the location of gravity highs on the seaward edge of terraces. (bottom) Synthetic structural profile from Gaulier et al. [1988] based on a set of ESP seismic experiments oriented perpendicular to and centered on the profile shown here. The location of ESP lines is shown by arrows.

et al. [1988] carried out 13 ESP seismic experiments within the Red Sea. The seven seismic lines located more than $30 \mathrm{~km}$ from the coast but not in the axial depressions gave depth to Moho of 10.5$14.5 \mathrm{~km}$. On five of the seven, the Moho was a depth of 13-14 km below the sea surface. The Moho therefore is relatively flat and does not exhibit the large relief present on the upper surface of the crust.

[24] Well-developed fault scarps are present along portions of the boundary of the axial depression (Figure 7) as well as at other locations. For example, Figure 9 shows a seismic reflection line (location shown in Figure 8) with a clearly faulted scarp (at $\mathrm{km}-30$ on the bathymetry profile) that can be traced for more than $10 \mathrm{~km}$ along strike on adjacent bathymetry profiles. Other linear bathymetric scarps are present throughout the main trough. In Figure 10b, linear scarps can be ob- served at about $\mathrm{km}-40$ on profiles ph45 - ph53 and at $\mathrm{km}-10$ on profiles ph55 and ph57. In all of these cases, the scarp is located just seaward of the peak of a free-air gravity high, supporting the interpretation that the gravity anomalies arise from relief on basement fault blocks. The presence of linear, apparently tectonic, scarps suggests that the faults bounding the crustal blocks are still active.

[25] Since the northern Red Sea is underlain by several $\mathrm{km}$ of evaporites [e.g., Whitmarsh et al., 1974; Miller and Barakat, 1988], it is perhaps surprising that the morphology reflects basement tectonics. In the Gulf of Suez, where the subsurface structure has been investigated in detail, and where the overburden is as great or greater than in the Red Sea, salt movement appears to be driven by tectonics and takes the form of salt walls that reflect the geometry of the underlying active faults [Bosworth et al., 1998; Orszag-Sperber et al., 


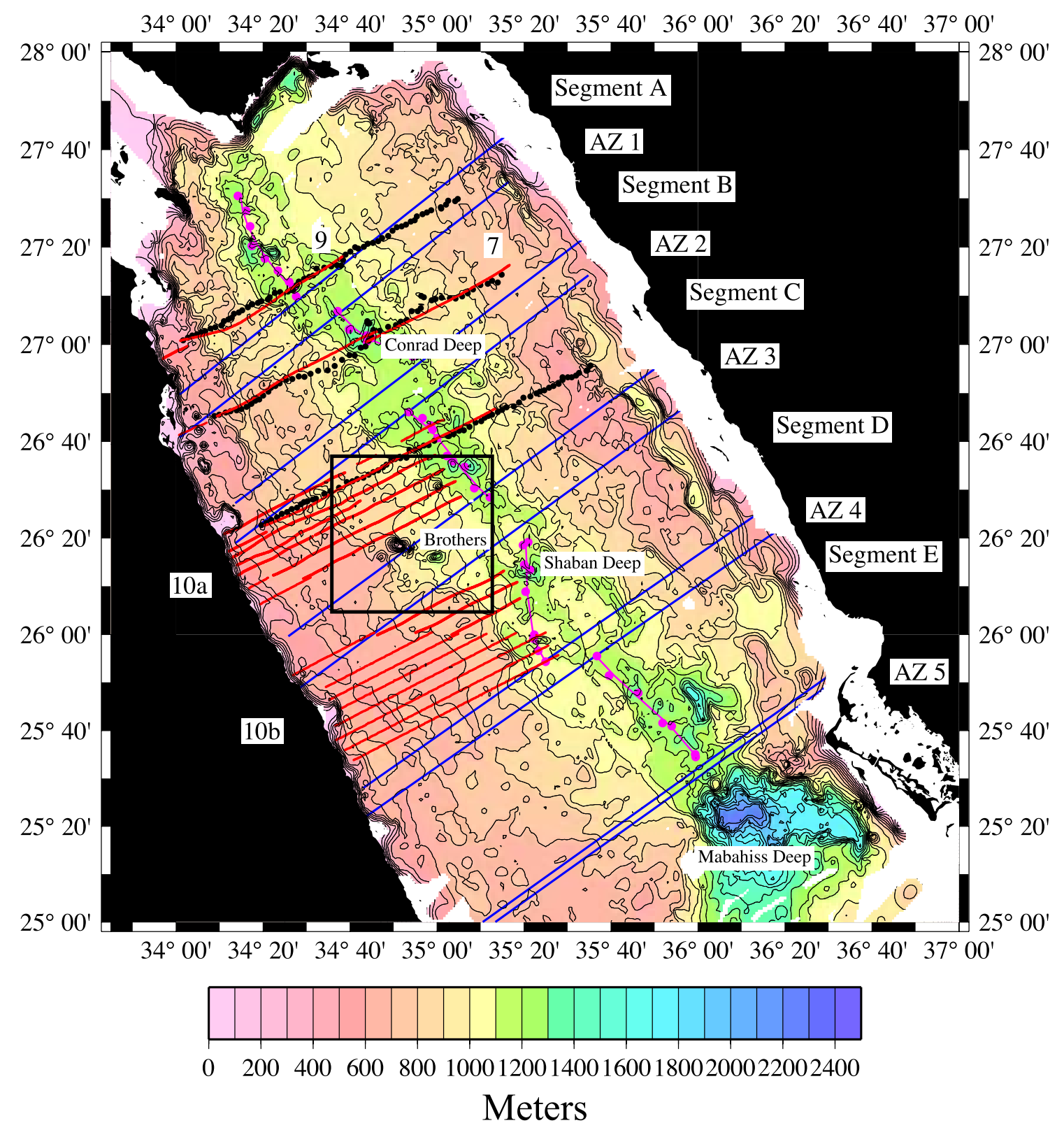

Figure 8. Map showing location of profiles shown in Figures 7, 9, 10a, and 10b. Segments and accommodation zones (AZ) are also labeled. Box outlines the region shown in Figures 16a and 16b. Location of heat flow data shown in Figure 17 is shown as black dots. Sets of blue lines delineate the location and extent of accommodation zones segmenting the rift. Purple dots mark the location of the rift axis identified on individual bathymetry and gravity profiles. The purple lines are smooth curves fit through the axis locations within each segment. Bathymetry is contoured at $100 \mathrm{~m}$ intervals.

1998a, 1998b]. Since, even in the Gulf of Suez where the overburden can be much greater than in the northern Red Sea, salt motion is controlled by and reflects tectonic activity, it is reasonable to assume that the seafloor morphology and gravity anomalies in the Red Sea are related to the basement structure and active tectonics. Thus even where scarps and slopes appear to occur in conjunction with diapiric features, such as near $\mathrm{km}-5$ on the profile in Figure 9, the linearity of the scarp and its relationship to the gravity anomalies lends assurance to the interpretation that it arises from and reflects the basement tectonics.

\subsection{Rift Segmentation}

[26] Examination of the bathymetry and gravity data allows definition of the along-axis segmenta- 

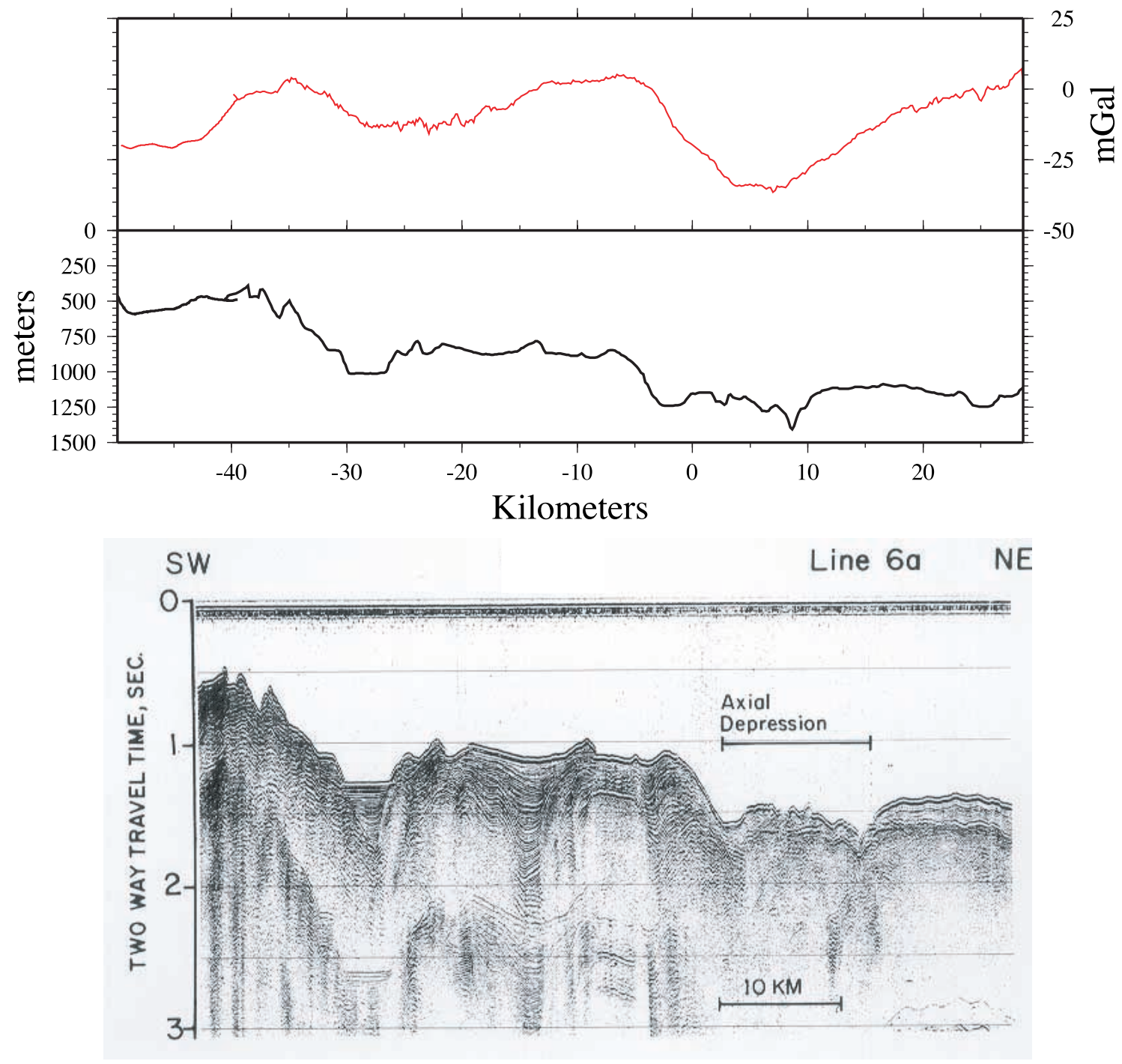

Figure 9. (bottom) Single channel seismic reflection line, and (top) bathymetry and free-air gravity anomaly profiles from the northern Red Sea (location shown in Figure 8). Note presence of clearly tectonic fault near $\mathrm{km}-30$ on bathymetry profile. Scarp near $\mathrm{km}-5$ on the bathymetry profile is underlain by a salt wall extending for $>10 \mathrm{~km}$ along axis, implying that it is tectonically controlled. Also note deformed sediments within the axial depression. Bathymetry and gravity profiles are projected along $\mathrm{N} 60^{\circ} \mathrm{E}$ with west to the left.

tion within the northern Red Sea. Figures 8, 11a, $11 \mathrm{~b}, 12 \mathrm{a}$, and $12 \mathrm{~b}$ show the location of five accommodation zones extending across the northern Red Sea rift and segmenting it into welldefined tectonic segments. The accommodation zones are identified primarily by offsets and truncations of rift parallel bathymetric and gravity contours. The segmentation is clearest at the axial depression. The axis consists of a series of discrete depressions offset from each other and separated by slightly shallower areas (Figures 3, 11a, and $11 \mathrm{~b}$ ). The axial depression generally deepens away from accommodation zones toward a small deep located near the center of each segment. The profile in Figure 7 crosses Conrad Deep in Segment $\mathrm{B}$. The segmentation of the axis is especially clear in the free-air gravity anomalies, which show a similar pattern of larger gravity lows in the center of segments with the gravity minimum becoming less negative toward the accommodation zones where there is an offset in the gravity low (Figures 4a, 12a, and 12b).

[27] Sets of bathymetric and gravity profiles from Segments C and D spaced 4-7 km apart and projected perpendicular to the strike of the rift are shown in Figures 10a and 10b (location of profiles is shown in Figure 8). Within each segment, 

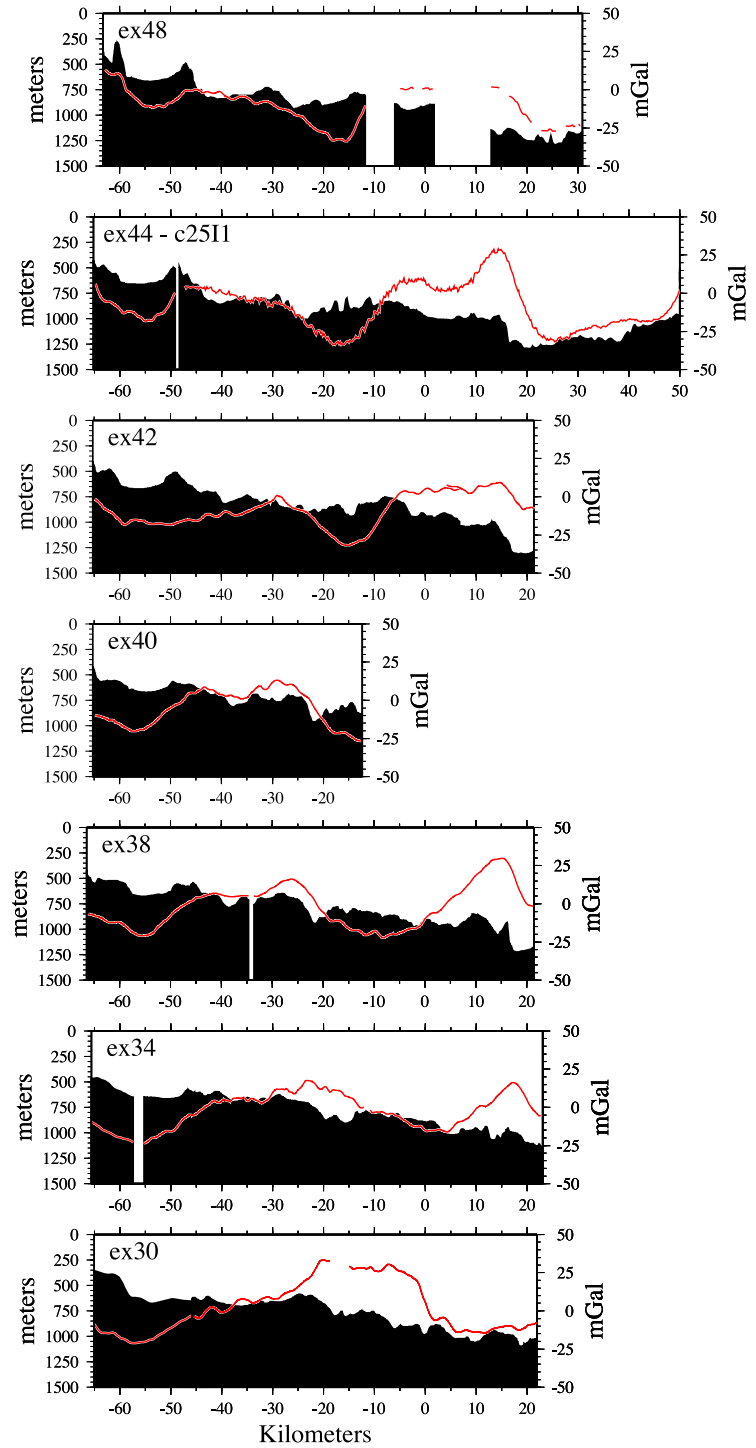

Figure 10a. Bathymetry and free-air gravity anomaly profiles from the western portion of Segment $\mathrm{C}$ of the northern Red Sea. Profiles are projected along $\mathrm{N} 60^{\circ} \mathrm{E}$ with west to the left. Location of profiles is shown in Figure 8. Northernmost profile is at the top. Profile names are ex (for Exxon Red Sea survey) and line number within that survey [Barakat and Miller, 1984; Miller and Barakat, 1988]. Line C25I1 is from a 1984 R/V Robert D. Conrad survey [Martinez and Cochran, 1988].

bathymetry features and gravity anomalies show continuity along-strike. Individual features evolve in shape and amplitude, but can be traced as distinct entities for the length of the segment. The continuity of the gravity high and bathymetric gradient marking the edge of the axial depression (at $\sim \mathrm{km} 15$ in Segment $\mathrm{C}$ and $\mathrm{km} \mathrm{5-10} \mathrm{in}$ Segment D) is particularly clear in both segments (Figures 10a and 10b).
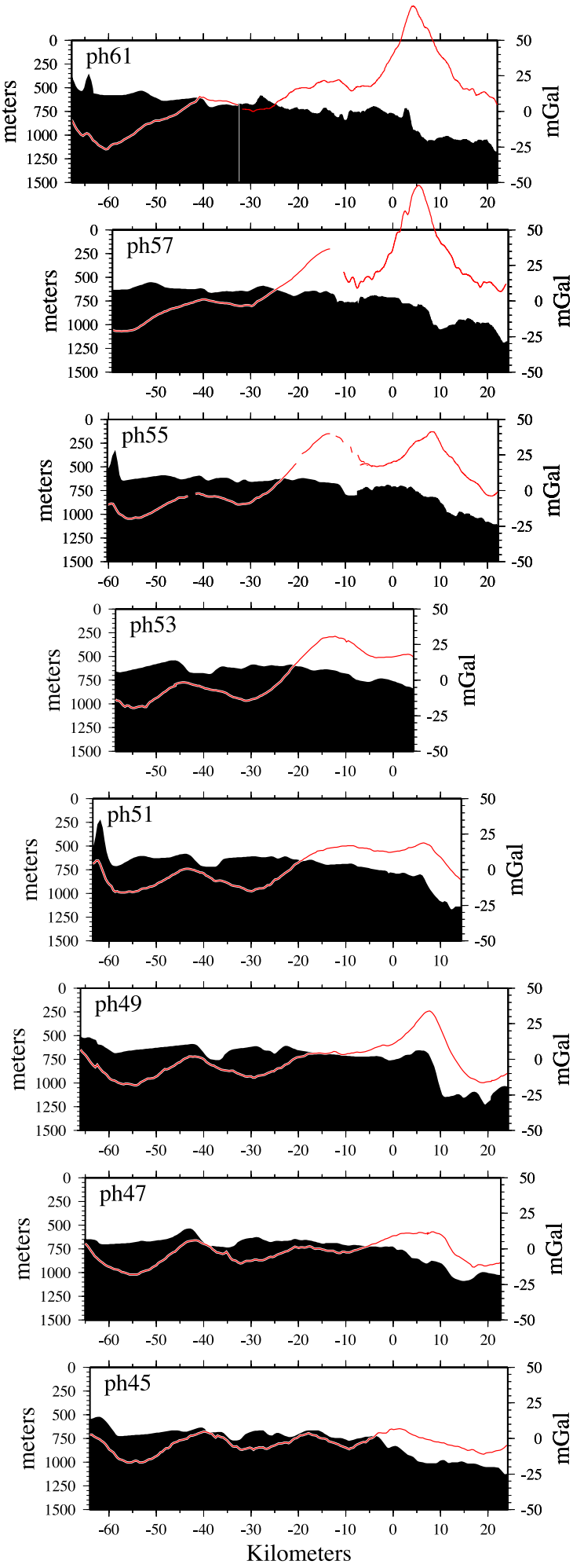

Figure 10b. Bathymetry and free-air gravity anomaly profiles from the western portion of Segment D of the northern Red Sea. Profiles are projected along N60 ${ }^{\circ} \mathrm{E}$ with west to the left. Location of profiles is shown in Figure 8. Northernmost profile is at the top. Profile names are ph (for Phillips Red Sea survey) and line number within that survey. 


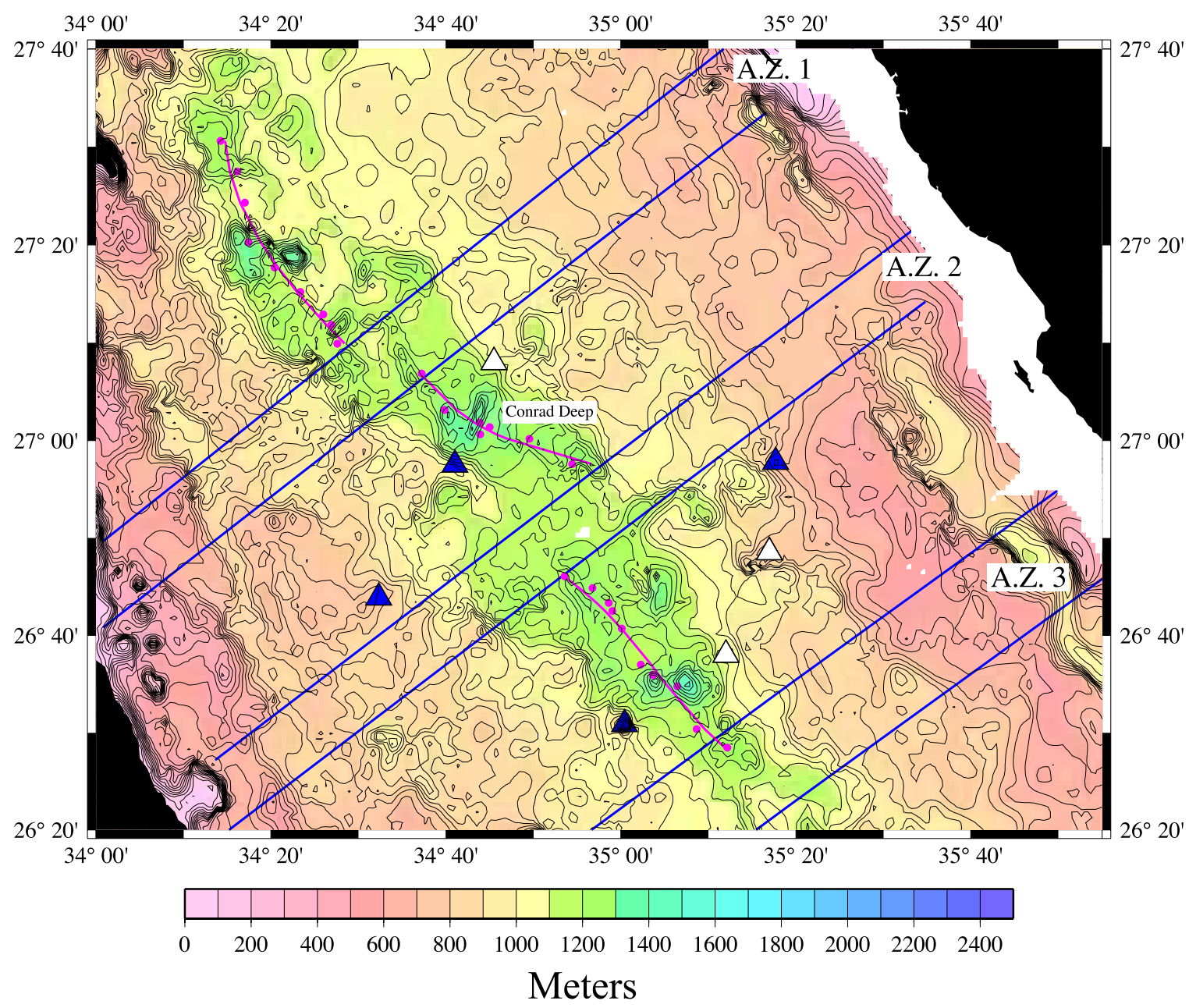

Figure 11a. Bathymetry map of the axial portion of the northern Red Sea from $26^{\circ} 20^{\prime} \mathrm{N}$ to $27^{\circ} 40^{\prime} \mathrm{N}$ contoured at $50 \mathrm{~m}$ intervals. Sets of blue lines delineate the location of accommodation zones segmenting the rift. Purple dots mark the location of the rift axis identified on individual bathymetry and gravity profiles. The purple lines are smooth curves fit through the axis locations within each segment. Triangles mark location of volcanoes identified from magnetic anomalies (Figure 6). The triangles are blue when the identification is confirmed by bathymetry or gravity data and white when based only on magnetics data.

[28] The continuity of bathymetry and gravity features breaks down at the ends of segments. The seaward end of profile ph45 (Figure 10b) intersects Accommodation Zone 4 (AZ4) (Figure 8) and the gravity high and bathymetric gradient marking the edge of the axial depression, located at $\mathrm{km} 5$ to10 throughout the segment, is not present on that profile. Similarly profile ex30 (Figure 10a) is located very close to AZ3 (Figure 8). The axial depression-bounding gravity high located near $\mathrm{km}$ 15 throughout the length of the segment is not present on profile ex30 and the boundary of the axial depression is gradual and indistinct. The large gravity anomaly located between $\mathrm{km} 0$ and $\mathrm{km}-20$ on profile ex30 arises from the Brothers Islands, located about $3 \mathrm{~km}$ south of the profile
(Figure 8). The Brothers are a fragment of mid- to lower-crustal gabbroic rocks [Shukri, 1944; Bonatti and Seyler, 1987; Hoang and Taviani, 1991] that appear to have been caught up in the accommodation zone and tectonically uplifted [Taviani et al., 1984; Bosworth, 1994].

[29] The onshore rift structure and its relationship to the offshore structures are well studied in the Gulf of Suez. The relationship between onshore and offshore structures is less clear along the Red Sea coast. However, at least in one case, there is a clear correspondence between the accommodation zones identified in the Red Sea and rift segmentation observed on land in Egypt. Jarrige et al. [1990] identified a reversal in the sense of dip on 


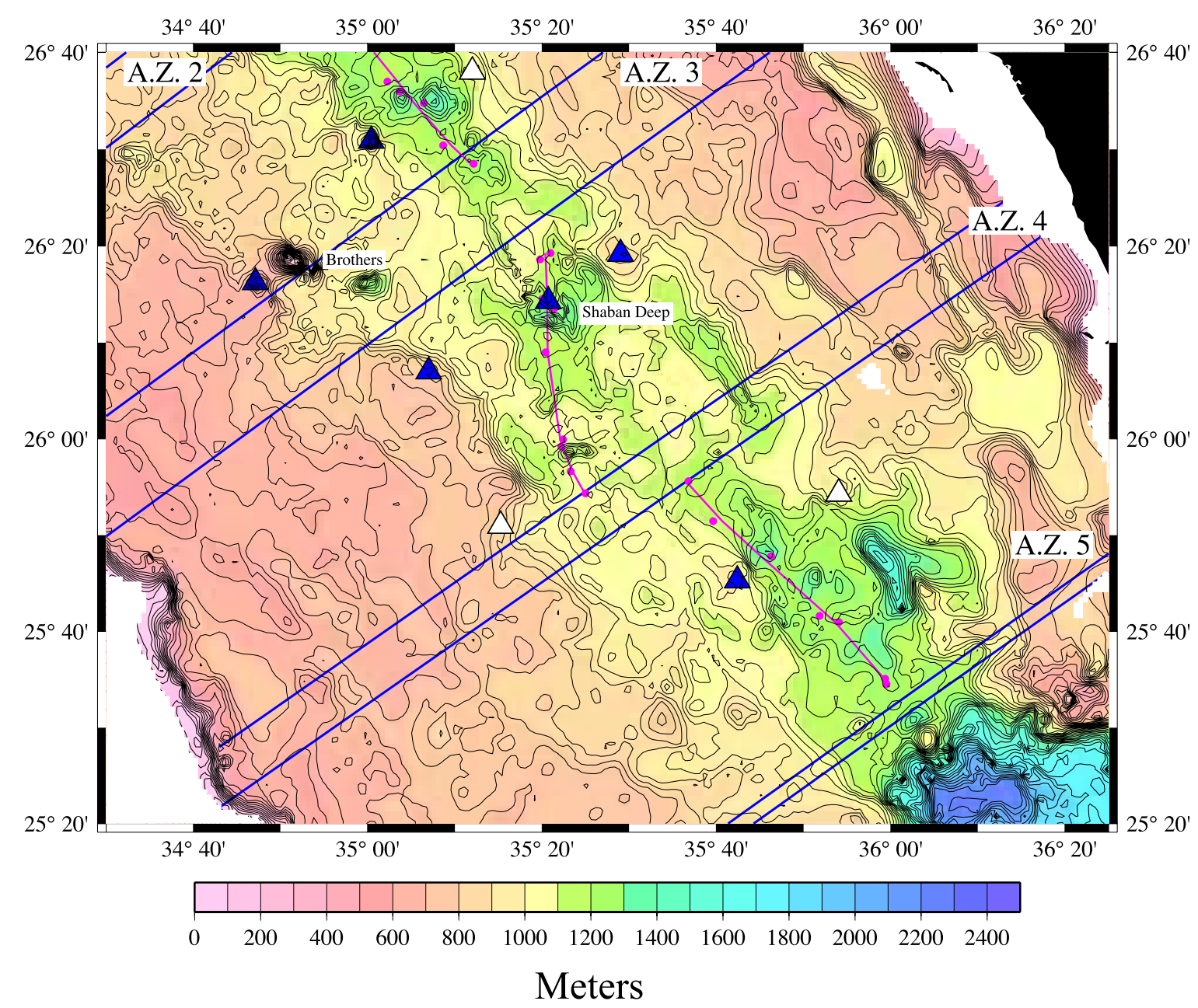

Figure 11b. Bathymetry map of the axial portion of the northern Red Sea from $25^{\circ} 20^{\prime} \mathrm{N}$ to $26^{\circ} 40^{\prime} \mathrm{N}$ contoured at $50 \mathrm{~m}$ intervals. Sets of blue lines delineate the location of accommodation zones segmenting the rift. Purple dots mark the location of the rift axis identified on individual bathymetry and gravity profiles. The purple lines are smooth curves fit through the axis locations within each segment. Triangles mark location of young $(<780 \mathrm{kyr})$ volcanoes identified from magnetic anomalies (Figure 6). The triangles are blue when the identification is confirmed by bathymetry or gravity data and white when based only on magnetics data.

rotated fault blocks near $26^{\circ} 20^{\prime} \mathrm{N}$ at the northern end of the Gebel Um Hammad-Gebel Duwi block (Figure 13) that was mapped and discussed in detail by Moustafa [1997, 2002] and Younes and McClay [2002]. Moustafa [2002] calls this feature the Sudmain Transfer Zone and Younes and McClay [2002] refer to it as the Duwi Accommodation Zone. This reversal in dip is directly in line with the landward extension of AZ2 (Figure 13).

[30] Possible landward continuations of the other accommodation zones are not as obvious. AZ1 projects to the coast at $26^{\circ} 40^{\prime}-26^{\circ} 45^{\prime} \mathrm{N}$ near Safaga Island, while AZ3 reaches the coast near $26^{\circ} \mathrm{N}$ (Figures 3 and 13). There is not a reversal in the dip direction of fault blocks at either location
(Figure 13). However, the pattern of rift-parallel faults bounding large crustal blocks is disrupted and offset at both locations. Moustafa [2002] described a NNE-SSW trending transfer fault connecting the eastern bounding faults of the Gebel Um Hammad-Gebel Duwi block and the Gebel Hamadat blocks near $26^{\circ} \mathrm{N}$ in line with AZ3 (Figure 13). The offset between the two fault blocks is about $10 \mathrm{~km}$. In the north, at the location of AZ1, Bosworth et al. [1998] describes a zone of E-W cross-faults extending for about $10 \mathrm{~km}$ south of Gebel Um Tagher (Figure 13) that segment the rift-parallel faults. Bosworth et al. [1998] interpret the cross-faults to have formed synchronously with the main normal faults, acting as relays between normal faults. It is possible that these two disrup- 


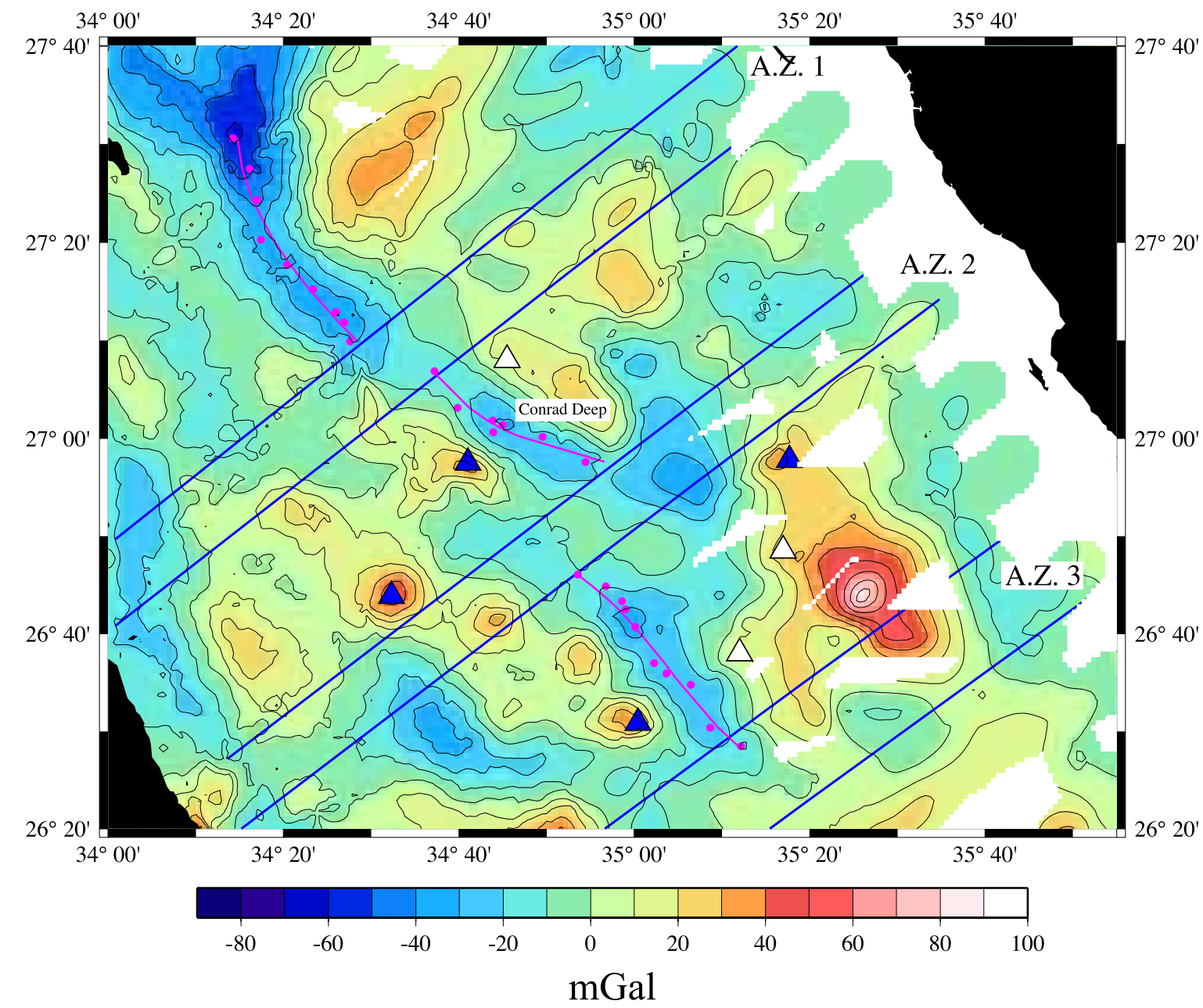

Figure 12a. Free-air gravity anomaly map of the axial portion of the northern Red Sea from $26^{\circ} 20^{\prime} \mathrm{N}$ to $27^{\circ} 40^{\prime} \mathrm{N}$ contoured at $10 \mathrm{mGal}$ intervals. Sets of blue lines delineate the location of accommodation zones segmenting the rift. Purple dots mark the location of the rift axis identified on individual bathymetry and gravity profiles. The purple lines are smooth curves fit through the axis locations within each segment. Triangles mark location of volcanoes identified from magnetic anomalies (Figure 6). The triangles are blue when the identification is confirmed by bathymetry or gravity data and white when based only on magnetics data.

tions of the pattern of rift-parallel normal faults bounding rotated fault blocks result from segmentation of the early continental rift at which the polarity of the initial rift half grabens did not reverse.

[31] AZ4, which projects to the coast near $25^{\circ} 25^{\prime} \mathrm{N}$, coincides with a linear band of high seismicity on a recent compilation from the Egyptian national seismic network by the National Research Institute for Astronomy and Geophysics (NRIAG) (A. Badawy, personal communication, 2004). This linear band of small earthquakes extends from at least the Red Sea axis past the coast and extends inland through Abu Dabbab, which has been the site of numerous recorded earthquakes with magnitudes as great as 5.1 [Daggett et al., 1986;
Kebeasy, 1990]. Seismicity farther north in the Red Sea is more diffuse and it is not possible to correlate the other accommodation zones with increased seismicity.

[32] Bosworth [1994] has proposed a segmentation pattern for the northern Red Sea based on outcrop observations of polarity reversals along both margins of the Red Sea. This methodology results in much longer segments $(\sim 150 \mathrm{~km})$ and accommodation zones that are oblique the opening direction. The segmentation observed in the offshore marine portion of the Red Sea is both more orthogonal and shorter wavelength. This difference appears to result from the fact that the segmentation that developed offshore utilized transfer zones where there was not a rift polarity reversal. 


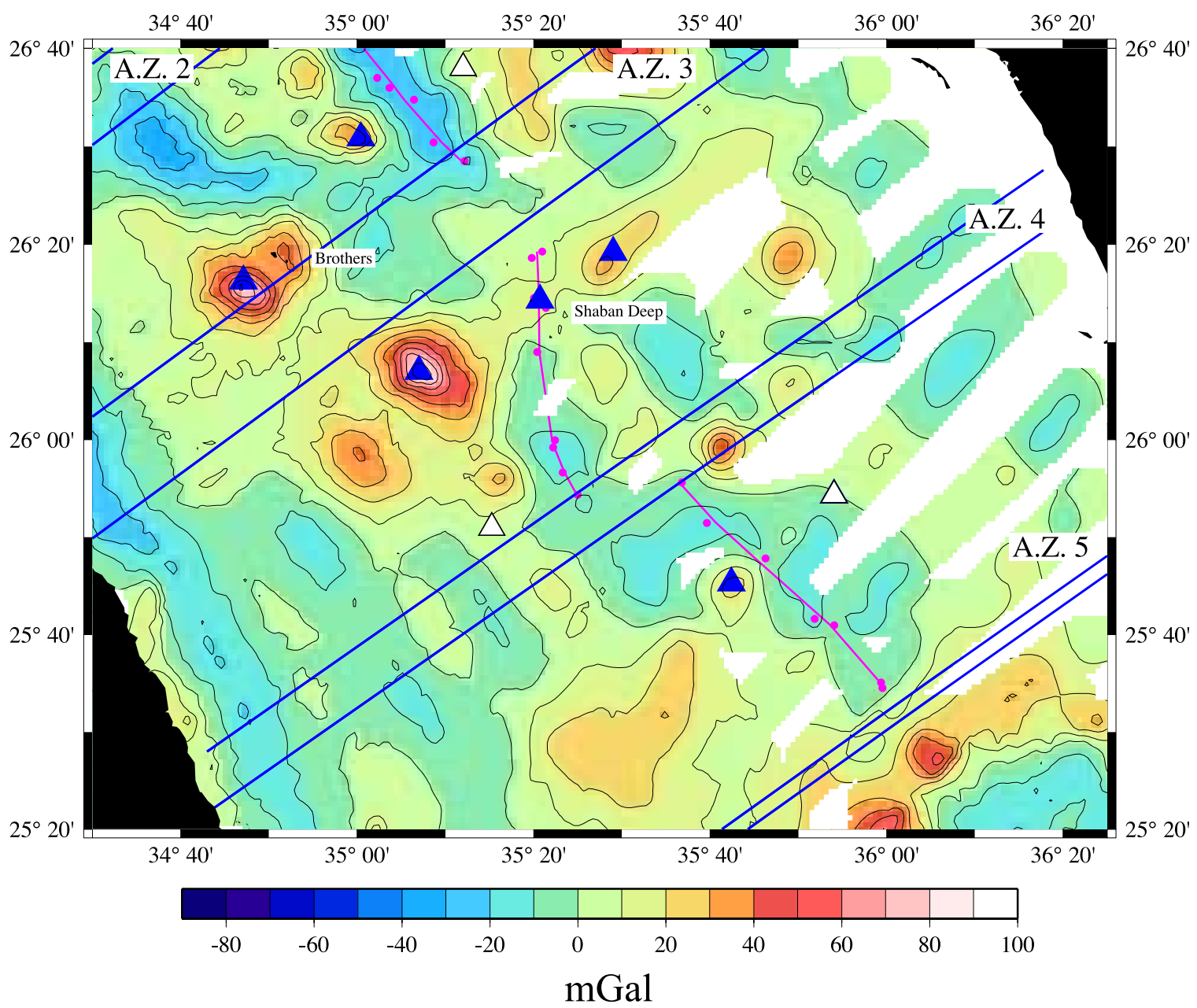

Figure 12b. Free-air gravity anomaly map of the axial portion of the northern Red Sea from $25^{\circ} 20^{\prime} \mathrm{N}$ to $26^{\circ} 40^{\prime} \mathrm{N}$ contoured at $10 \mathrm{mGal}$ intervals. Sets of blue lines delineate the location of accommodation zones segmenting the rift. Purple dots mark the location of the rift axis identified on individual bathymetry and gravity profiles. The purple lines are smooth curves fit through the axis locations within each segment. Triangles mark location of volcanoes identified from magnetic anomalies (Figure 6). The triangles are blue when the identification is confirmed by bathymetry or gravity data and white when based only on magnetics data.

[33] There is a fundamental difference between the nature of the exposed onshore accommodation zones and those in the very extended marine portion of the northern Red Sea rift. The accommodation zones exposed on the margin are narrow zones of deformation offsetting individual fault blocks and often not orthogonal to the trend of the rift [Moustafa, 1997, 2002; Bosworth et al., 1998; Younes and McClay, 2002] (Figure 13). In contrast, the accommodation zones within the marine northern Red Sea are broader zones oriented parallel to the opening direction. Continental rift segmentation has been extensively studied in the East African Rift where it has been found to be complex, sinuous and often oblique to the extension direction [e.g., Bosworth, 1985; Bosworth et al., 1986; Ebinger, 1989a, 1989b; Burgess et al., 1988]. This type of segmentation is observed along the margins of the northern Red Sea and in the Gulf of Suez. This type of oblique accommodation zone appears able to allow the amount of extension that has occurred in the basins of the Gulf of Suez [Patton et al., 1994]. Roughly $125 \mathrm{~km}$ of extension has occurred in the northern Red Sea, which is about five times that in the Gulf of Suez. One result of the large amount of extension in the Red Sea is that the accommodation zones appear to have been rotated to be more parallel to each other and to the opening direction. They are still relatively broad zones, as found in the Gulf of Suez, with differential motion probably accommodated on a number of different faults, 


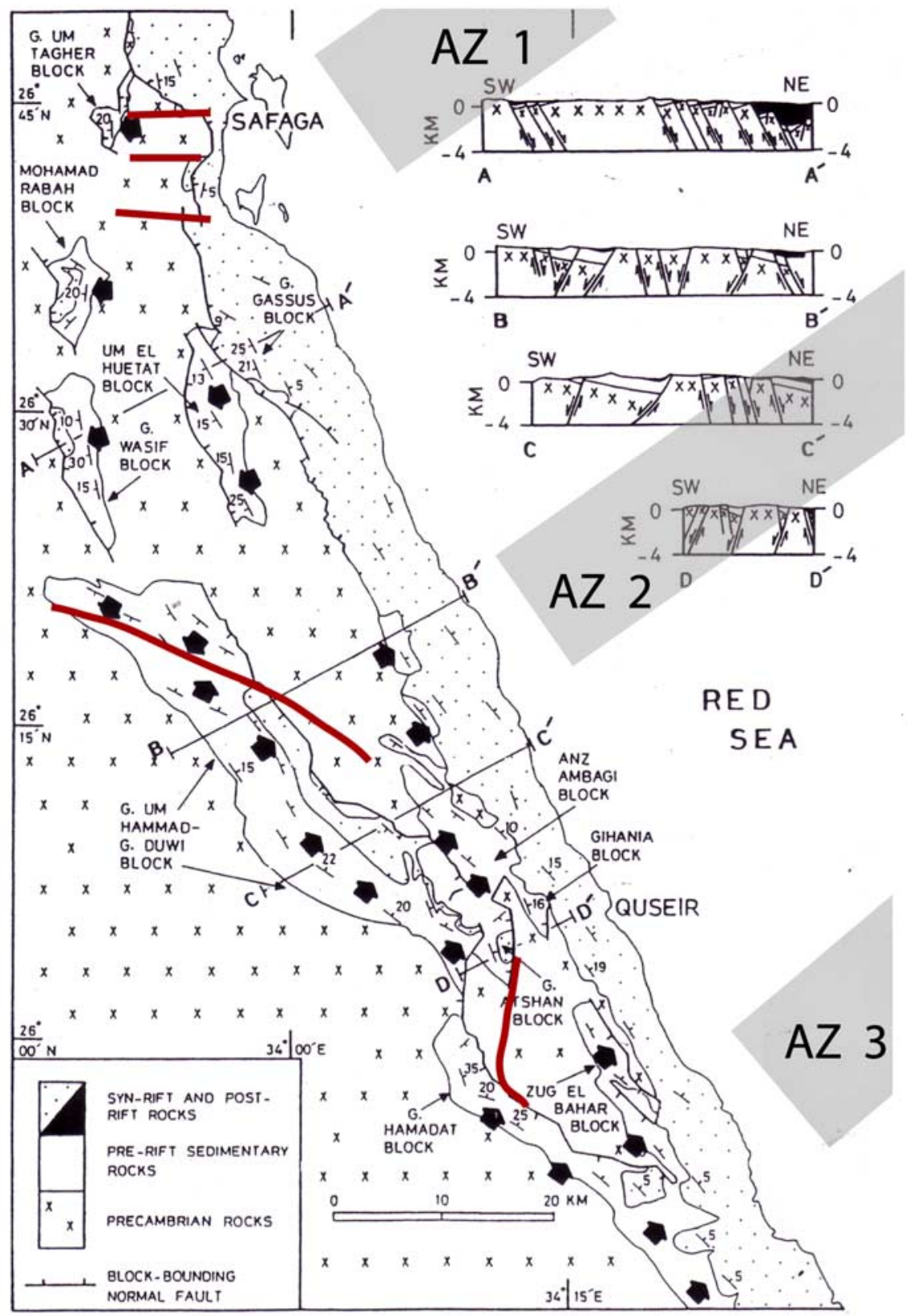

Figure 13. Possible location of landward extensions of the accommodation zones identified offshore superimposed on a structural map modified from Moustafa [2002]. Structural features described by Jarrige et al. [1990], Moustafa [1997, 2002], Bosworth et al. [1998], and Younes and McClay [2002] that are possible accommodation zones as discussed in the text are shown in red. AZ2 projects ashore at a location where the polarity of dip on crustal fault blocks reverses. AZ1 and AZ3 project ashore where polarity does not reverse but where the pattern of rift-parallel faults is disrupted and offset. Basemap from Moustafa [2002] is copyright 2002 by AAPG and reprinted by permission of AAPG, whose permission is required for further use.

rather than a single throughgoing fault as observed at oceanic transforms.

\subsection{Rift Volcanism}

[34] Virtually no syn-rift volcanism has been reported from the exposed margins of the northern Red Sea rift. On the Sinai margin of the Gulf of
Suez, the Abu Zenima formation (earliest syn-rift red beds) is capped by a basalt flow [Plaziat et al., 1998b; Bosworth and McClay, 2001] that has been dated at $21 \mathrm{Ma}$. Other scattered dikes and flows in Sinai have been dated at 22-27 Ma [Meneisy, 1990; Plaziat et al., 1998b; Bosworth and McClay, 2001] and a few basalt flows near Quseir $\left(26^{\circ} 05^{\prime} \mathrm{N}\right)$ on the Egyptian Red Sea coast have been dated at 


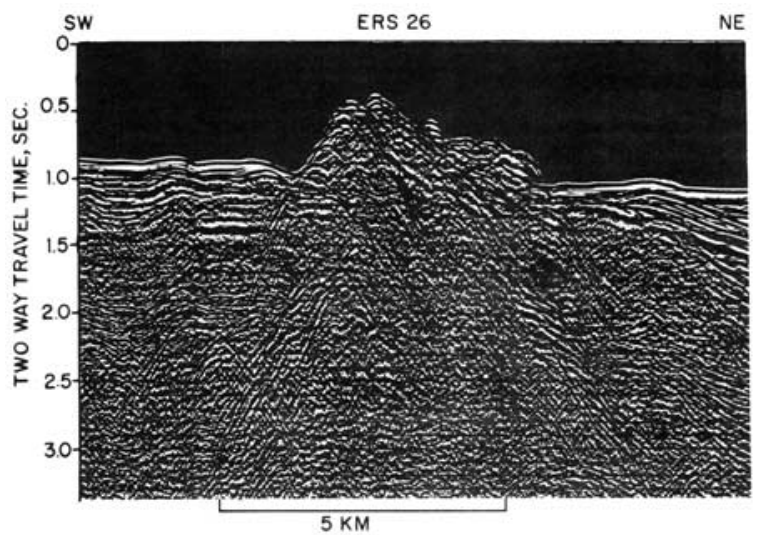

Figure 14. Seismic reflection profile across a bathymetric high interpreted as a small volcano by Martinez and Cochran [1988] located $7.5 \mathrm{~km}$ southwest of the Brothers Islands near the intersection of Accommodation Zone 3 with a bathymetric terrace within Segment C. Location of the seismic line is shown in Figures 16a and $16 \mathrm{~b}$.

23-25 Ma [Meneisy, 1990; Plaziat et al., 1998b]. After this early episode, rifting in the northern Red Sea appears to have been largely amagmatic.

[35] Diabase dikes and sills have been described from Zabargad [e.g., El Shazly et al., 1974; Bonatti et al., 1983; Nicolas et al., 1987; Bosworth et al., 1996] and the Brothers Islands [Shukri, 1944; Taviani et al., 1984]. Both locations are uplifted slivers of crustal and mantle rocks, with prerift sedimentary rocks present on Zabargad [e.g., Bonatti et al., 1983; Bosworth et al., 1996]. ${ }^{40} \mathrm{Ar} /{ }^{39} \mathrm{Ar}[$ Villa, 1990] and U-Pb [Oberli et al., 1987] dating suggests Miocene ages of 18.5-20 Ma for the dikes on Zabargad. Nicolas et al. [1987] have suggested a Pleistocene age for one set of dikes based on stratigraphic relationships.

[36] The total intensity magnetic anomaly map (Figure 6) shows two patterns of magnetic anomalies within the marine portion of the northern Red Sea. The southeast corner of the map, in the vicinity of Mabahiss Deep, contains a series of large amplitude anomalies that are lineated in a NW-SE direction. The remainder of the northern Red Sea exhibits a relatively flat magnetic field on which a number of large-amplitude dipolar anomalies are superimposed.

[37] Mabahiss Deep is a large escarpment-bounded pull-apart basin with areas of outcropping basaltic flows on its floor [Pautot et al., 1986; Guennoc et al., 1988, 1990]. It is located at the northern end of a N-S oriented portion of the Red Sea axis that is at a large angle to the opening direction (Figure 1).
Zabargad Island, a compressional feature exposing mantle rocks [El Shazly and Saleeb, 1979; Bonatti et al., 1981, 1983; Nicolas et al., 1987], is located along the western Red Sea margin at the southern end of the N-S trending region. Dixon et al. [1987] and Crane and Bonatti [1987] argue that this oblique portion of the Red Sea axis results from the interaction of the rifting with a Precambrian lineament, the Onib-Hamisana suture. Crane and Bonatti [1987] also argue that the extension resulting in Mabahiss Deep and the compression responsible for the formation of Zabargad both result from this interaction.

[38] Magnetic anomalies in the Red Sea to the north of Mabahiss Deep are all dipolar anomalies (Figure 6) implying a compact localized source. These anomalies have been interpreted as arising from discrete localized volcanoes [Cochran et al., 1986; Martinez and Cochran, 1988; Guennoc et al., 1988]. In a number of cases, this inference has been verified by direct observation of a small volcanic structure (Figures 14 and 15) [Martinez and Cochran, 1988; Guennoc et al., 1990]. The locations of volcanoes implied by the magnetic anomaly map are shown as triangles in Figures $11 \mathrm{a}, 11 \mathrm{~b}, 12 \mathrm{a}$, and $12 \mathrm{~b}$. Where this inference is confirmed by bathymetry and/or gravity data, the triangle is blue. In the cases where
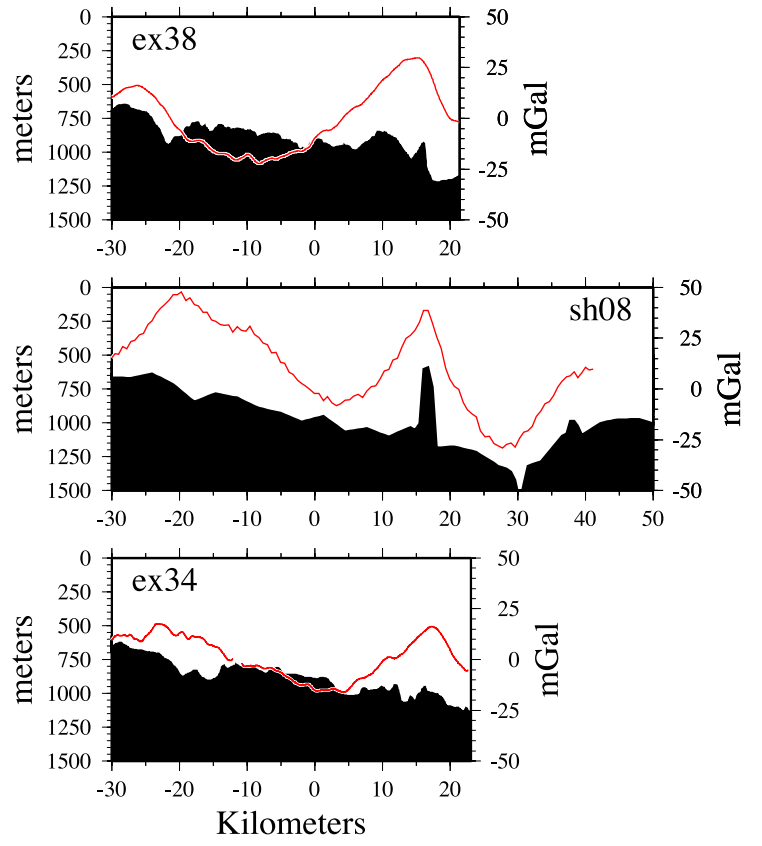

Figure 15. Bathymetry and free-air gravity profiles across a volcano located at the edge of the axial depression within Segment C. Location of the profiles is shown in Figures 16a and 16b. Profiles are projected along $\mathrm{N} 60^{\circ} \mathrm{E}$ with west to the left. 
there is not other supporting evidence, the triangle is white. The location of the volcano shown at $26^{\circ} 07^{\prime} \mathrm{N}, 25^{\circ} 07^{\prime} \mathrm{E}$ to the west of the axis in Segment $\mathrm{D}$ is based primarily on the observation of a seamount at that location reaching to $380 \mathrm{~m}$ of the sea surface ( $\sim 400 \mathrm{~m}$ above the surrounding seafloor) [Guennoc et al., 1988] that coincides with the location of a large gravity high (Figures $4 a, 4 b$, and $12 \mathrm{~b}$ ). The magnetics data alone would suggest that this volcano is located $\sim 10 \mathrm{~km}$ farther to the east. All of the dipolar magnetic anomalies in the northern Red Sea imply a normally magnetized source. This observation suggests that the volcanism is recent and has occurred within the last 780 kyr.

[39] Volcanoes within the northern Red Sea systematically occur at two distinct locations. There is a set of volcanoes that are located on the edge of bathymetric terraces immediately adjacent to accommodation zones. The small structure piercing through the sediments on the seismic line in Figure 14, located at the intersection of the seaward edge of a terrace with AZ3 (Figure 11b), was interpreted by Martinez and Cochran [1988] as a small volcano. A three-dimensional seismic survey suggests that this structure may be a rotated fault block rather than a volcano (W. Bosworth, personal communication, 2004). If the exposed structure imaged in Figure 14 is a shallow or uplifted corner of a rotated fault block, this could help explain the very large gravity anomaly at that site. However, it will not explain the large dipolar magnetic anomaly, which requires a large intrusion at that location, apparently utilizing the faults bounding the block as a conduit. Note that the nearby Brothers Islands, which are uplifted crustal slivers [Taviani et al., 1984; Bonatti and Seyler, 1987; Bosworth, 1994], do not have an associated magnetic anomaly (Figure 6). Other volcanoes are similarly located at the edge of bathymetric terraces adjacent to AZ2 and AZ4 (Figures 3, 4a, 4b, 11a, 11b, 12a, and 12b). An additional volcano, suggested by magnetics data but not substantiated by other observations, is located at the edge of a terrace near the center of Segment $C$ to the east of the axis (Figure 6).

[40] The other location at which observed and inferred volcanoes are located is along the edge of the axial depression. These volcanoes are generally not located at the axis, but rather are on the edge of the first terrace bounding the axial depression (Figure 15) [Cochran et al., 1986]. With the exception of Segment A, the northernmost segment, there are two axis-flanking volcanoes within each seg- ment, one on each side of the axial depression immediately adjacent to the small deep within that segment (Figures 11a and 11b) [Cochran et al., 1986]. At Segment D, in addition to the two volcanoes flanking the axial depression, a volcano is located at the axis, within Shaban Deep [Pautot et al., 1984]. The consistent occurrence of volcanoes at the edge of terraces, whether along the axial depression or elsewhere within the main trough, suggests that magma utilizes the faults bounding the large rotated crustal blocks as a path to the surface [Cochran et al., 1986]. The single exception is the volcano mapped within Shaban Deep by Pautot et al. [1984] in Segment D. The swath bathymetry data show that although this volcano is elongated along the axis, it is clearly an isolated central volcano and not a volcanic ridge [Pautot et al., 1984]. This is also supported by the gravity and magnetics data (Figures 4a, 6, and 12b).

[41] Figures 16a and 16b show bathymetry and gravity contours for a portion of Segment C. Ship tracks for the seismic line shown in Figure 14 and the bathymetry and gravity lines shown in Figure 15 are shown in purple in Figures 16a and $16 \mathrm{~b}$. The off-axis volcano near $26^{\circ} 16^{\prime} \mathrm{N}, 34^{\circ} 47^{\prime} \mathrm{E}$ (Figure 14) and the axis-flanking volcano near $26^{\circ} 31^{\prime} \mathrm{N}, 35^{\circ} \mathrm{E}$ (Figure 15) are evident both as bathymetric and as gravity features. The location of the off-axis volcano near the intersection of an accommodation zone and the seaward edge of a bathymetric terrace is clear from the 200 m bathymetric gradient extending NW from the volcano.

[42] Figures 16a and 16b also show the location of available bathymetric and gravity measurements. Both of the observed volcanoes are areally quite small ( $<5 \mathrm{~km}$ across) and are each documented by a single bathymetric line. Without the RRS Shackleton profile, the systematic Exxon survey, with a line spacing of $\sim 6 \mathrm{~km}$ would not have revealed the presence of the axis-flanking volcano, although it might be inferred from the gravity anomalies. The location of another volcano inferred from magnetics data to be located near $26^{\circ} 38^{\prime} \mathrm{N}, 35^{\circ} 12^{\prime} \mathrm{E}$ is shown by a white triangle. The lower track density to the east of the axis allows a bathymetric and gravity feature the size of the volcano on the west side to be located at that position without being apparent on the shipboard data. The sh08 profile may cross the edge of this inferred volcano near $\mathrm{km} 38$ where there is an $\sim 100 \mathrm{~m}$ bathymetric high (Figure 15). The majority of the other unconfirmed volcanoes are also located in areas of sparse shipboard data on the 

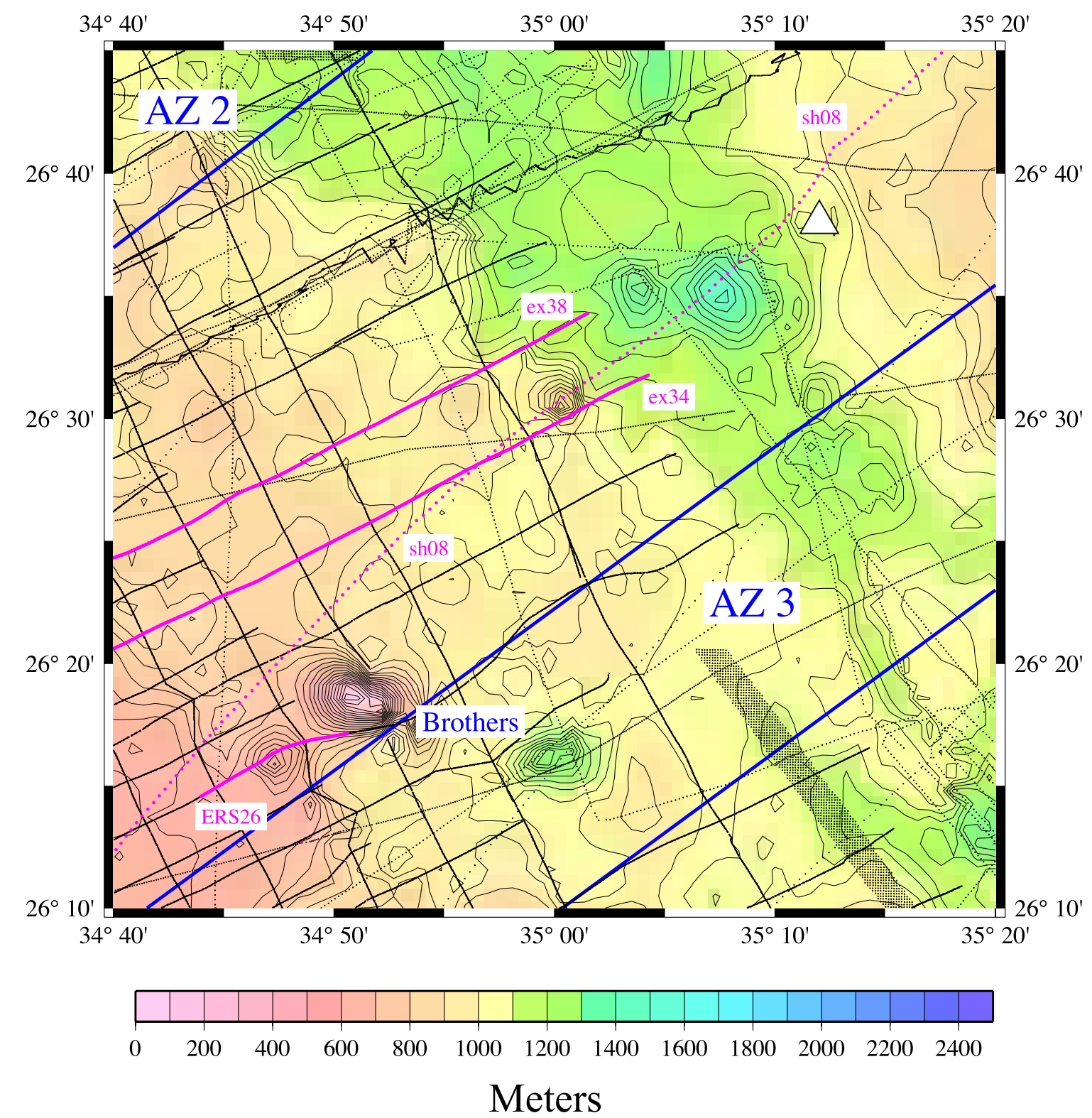

Figure 16a. Bathymetry map of a portion of the Red Sea axial depression and main trough near $26^{\circ} 30^{\prime} \mathrm{N}, 35^{\circ} \mathrm{E}$ contoured at $25 \mathrm{~m}$ intervals. Mapped area is shown in Figure 8. Heavy blue lines delineate accommodation zones. The location of bathymetry measurements is shown as black dots. The white triangle shows a location at which magnetics data suggest the presence of an additional volcano. Ship tracks of the profiles shown in Figures 14 and 15 are shown in purple. Seismic profile ERS26 corresponds to geophysical profile ex26. Line sh08 is RRS Shackleton profile 8.

Arabian side of the sea and it appears that the magnetics data provides the best measure of the location of recent volcanic activity.

\section{The Axial Trough and Transition From Continental Rifting to Seafloor Spreading}

[43] Seismic refraction experiments in the northern Red Sea have been interpreted as showing a crustal thickness of about $20 \mathrm{~km}$ along both the Egyptian and Saudi Arabian coasts [Makris et al., 1979, 1983; Rihm et al., 1991]. On the Egyptian side, the crust appears to reach its unrifted thickness of 30$35 \mathrm{~km}$ within $20-30 \mathrm{~km}$ of the coast [Rihm et al., 1991]. ESP 7 of Gaulier et al. [1988], located about $20 \mathrm{~km}$ offshore, gives a $9.1 \mathrm{~km}$ thick crust underlying $7.6 \mathrm{~km}$ of sediment so that the Moho is at $16.7 \mathrm{~km}$. Seven other ESPs, located more than $28 \mathrm{~km}$ from the coast, but not in the axial depression give crustal thicknesses of $5.1-8.3 \mathrm{~km}$ and 

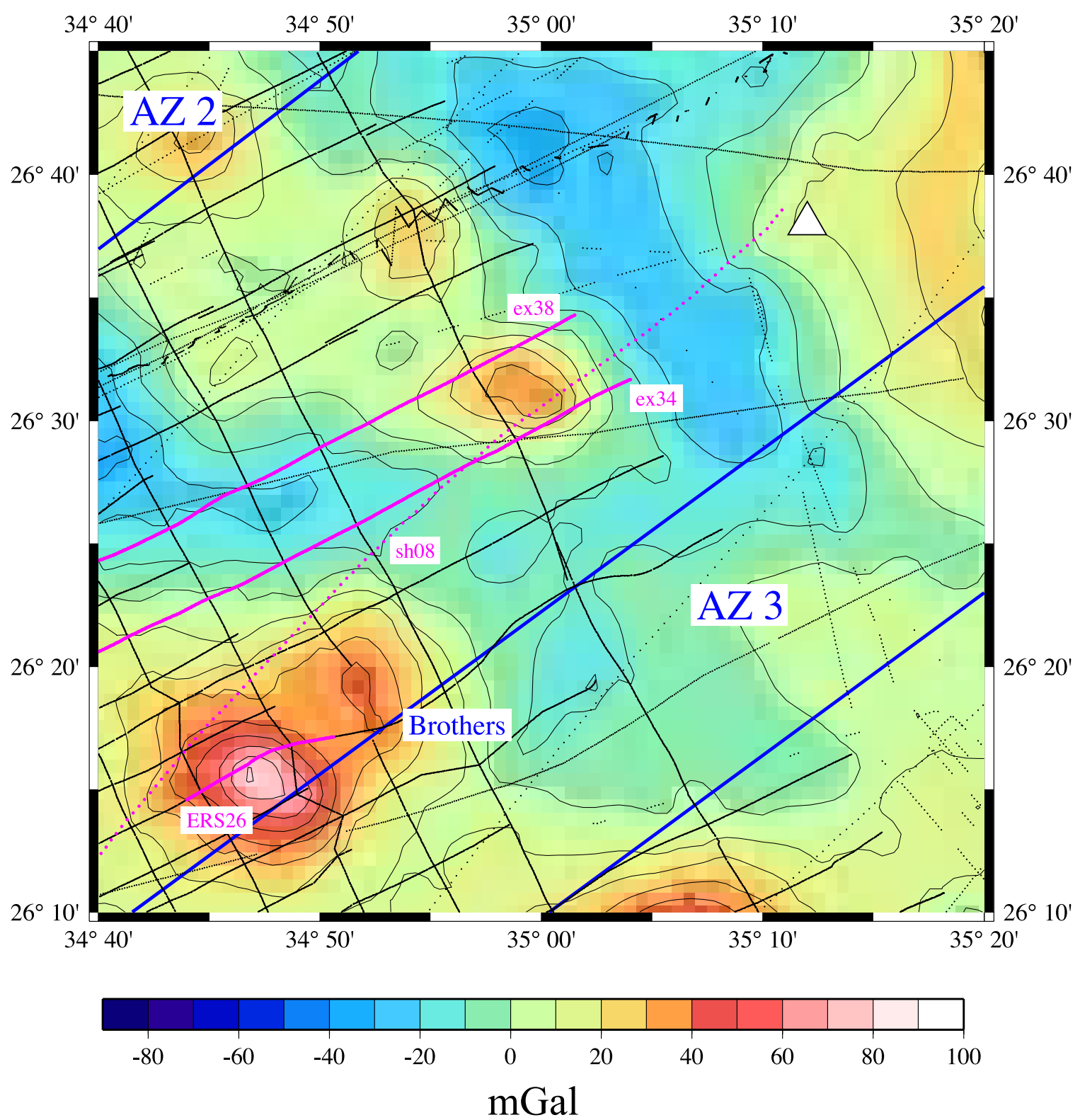

Figure 16b. Free-air gravity map of a portion of the Red Sea axial depression and main trough near $26^{\circ} 30^{\prime} \mathrm{N}, 35^{\circ} \mathrm{E}$ contoured at $10 \mathrm{mGal}$ intervals. Mapped area is shown in Figure 8. Heavy blue lines delineate accommodation zones. The location of gravity measurements is shown as black dots. The white triangle shows a location at which magnetics data suggest the presence of an additional volcano. Ship tracks of the profiles shown in Figures 14 and 15 are shown in purple. Seismic profile ERS26 corresponds to geophysical profile ex26. Line sh08 is RRS Shackleton profile 8.

depths to Moho of 10.5-14.5 km [Gaulier et al., 1988]. On six of these profiles, the depth to Moho is very uniform at $13-14.5 \mathrm{~km}$ below the sea surface. The crustal thickness determinations do not show a systematic relationship to distance from the margin. Gaulier et al. [1988] also ran five ESPs centered in the axial depression. These lines gave depths to Moho of 10-10.5 km with crustal thicknesses of $4.9-7.2 \mathrm{~km}$.
[44] There are no reliable crust thickness measurements from the Arabian side of the Red Sea. Rihm et al. [1991] report on three OBS seismic profiles run with air gun or seismic charge sources. None of these gave refracted mantle arrivals, although all three showed reflections at $10-12 \mathrm{~km}$ depth that were interpreted by Rihm et al. [1991] as arising from an intracrustal "Conrad" discontinuity. If instead, these reflections are interpreted as arising 
from the Moho, the inferred crustal thickness for these three profiles is $6.5-8 \mathrm{~km}$.

[45] The depth to Moho on the Egyptian side of the northern Red Sea is relatively constant at distances more than about $20 \mathrm{~km}$ from the coast, while the crustal thickness varies by $50 \%$ (Figure 7 ). These observations suggest that there has been extensive flow in the lower crust to relieve stress differences resulting from rotation of the large crustal blocks implied by the gravity anomalies and observed in the Gulf of Suez. In addition, almost all of the crustal thinning occurs over an approximately $50 \mathrm{~km}$ wide area centered on the present coastline. This observation also implies that extension has been evenly distributed across this portion of the Red Sea over most of the history of the rifting.

[46] The crustal structure of the Arabian side of the Red Sea is less well known, due primarily to the lack of reliable seismic data. The interpretation of offshore profiles by Rihm et al. [1991] differs significantly from that originally presented by Makris et al. [1983]. Makris et al. [1983] also presented a seismic refraction line extending into Arabia from the coast at $\sim 26^{\circ} \mathrm{N}$. Their interpretation shows a very gradual increase in crustal thickness extending over $100 \mathrm{~km}$ inland from the coast. Later discussions of the structure of the northern Red Sea by the same authors [Rihm et al., 1991; Makris and Rihm, 1991; Rihm and Henke, 1998] do not discuss this profile. On the basis of heat flow [Buck et al., 1988; Martinez and Cochran, 1989], bathymetry (Figure 3) and gravity (Figure 4a) data in the absence of definitive seismic data, we will assume that the structure of the Red Sea is basically symmetric.

[47] Although extension through most of the rift's evolution has been distributed relatively evenly across the Red Sea between the shelf-edge scarps, recent extension appears to have been concentrated at the axis. A number of investigators have commented that deformation within the sediment column is more intense within the axial depression than in the rest of the northern Red Sea [Knott et al., 1966; Guennoc et al., 1988; Martinez and Cochran, 1988]. Martinez and Cochran [1988] noted that their seismic reflection lines show that Reflector S (top of evaporites) appears folded and faulted in the axial depression, and that the sediments between $\mathrm{S}$ and the seafloor are frequently deformed conformably with S, indicating ongoing, active deformation (Figure 9). In contrast, they found that seismic profiles away from the axial depression generally show a decrease in deforma- tion from reflector $\mathrm{S}$ to the seafloor with individual reflectors frequently having onlapping terminations on lower ones. Marked discordances can be observed in places. Martinez and Cochran [1988] interpret these observations as indicating episodic tectonic activity and much less intense recent deformation than in the axial depression. Active faulting away from the axial depression appears to be concentrated on a few faults bounding the large rotated crustal blocks, often resulting in the formation of scarps (Figure 9).

[48] Martinez and Cochran [1988, 1989] presented three profiles of closely spaced heat flow measurements extending across the northern Red Sea. In all three profiles, heat flow increases from about $125 \mathrm{~mW} / \mathrm{m}^{2}$ near the margins to $250-350 \mathrm{~mW} / \mathrm{m}^{2}$ in the axial depression (Figure 17). The association of the maximum heat flow with the axial depression is particularly clear for the northern profile where the axial depression is offset toward the western portion of the Red Sea. Buck et al. [1988] and Martinez and Cochran [1989] modeled the heat flow resulting from different extension models including simple shear and a number of pure shear models in which the extending region either broadened with the rift or remained a constant width. They found that, to match the heat flow pattern, it is necessary that the zone of extension widen with the rift throughout most of the rifting history (for $\sim 20 \mathrm{myr}$ ), but narrows to a width comparable to the axial depression $(\sim 20 \mathrm{~km})$ within the last 5 myr. These models also suggest that melt may have begun to be generated very recently under the axis [Buck et al., 1988; Martinez and Cochran, 1989].

[49] Rifting in the northern Red Sea has been amagmatic through most of the rifting history. Scattered basaltic flows are associated with the very earliest stages of rifting [Meneisy, 1990; Plaziat et al., 1998b; Bosworth and McClay, 2001]. After this episode, there is no evidence of volcanism until the formation of a number of localized volcanic edifices within the rift. Magnetic anomalies (Figure 6) show that these small volcanoes are all normally magnetized and thus presumably have been erupted since $780 \mathrm{ka}$. These volcanoes are systematically located relative to the rift structure. They occur at the top of scarps or slopes marking the edge of terraces and appear to have ascended through the crust along faults. In particular, a pair of volcanoes are located across from each other on the scarps bounding the axial 
Northern
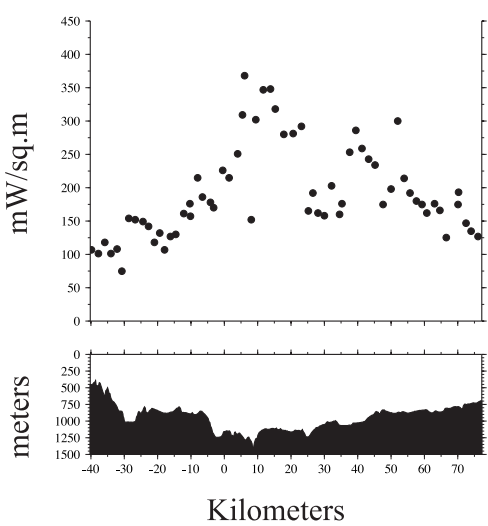

Central

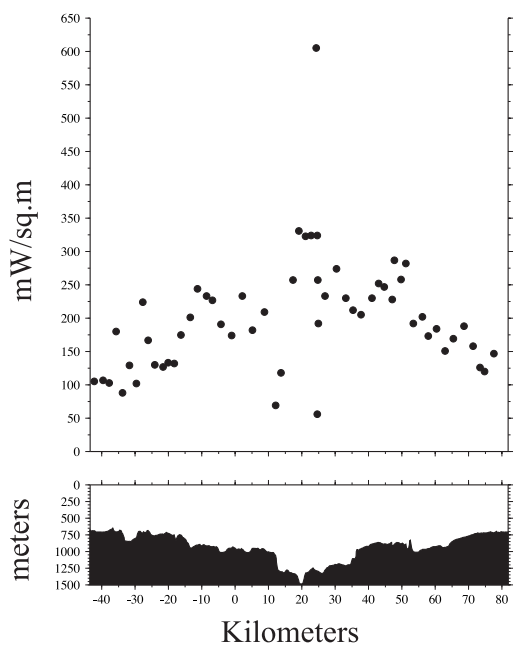

Southern

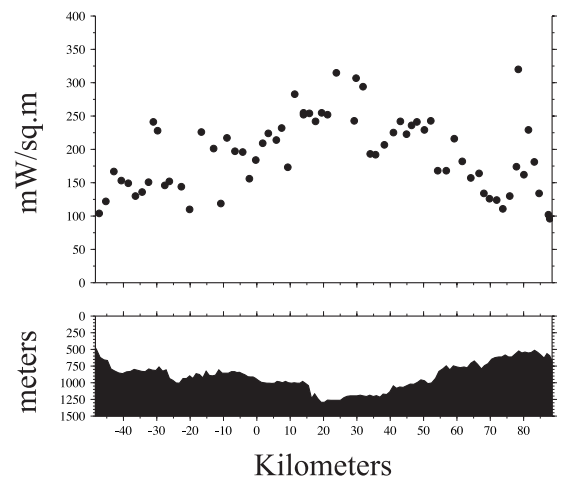

Figure 17. Heat flow profiles across the northern Red Sea. Location of the measurements is shown in Figure 8. Bathymetry and heat flow data are projected along an azimuth of $\mathrm{N} 60^{\circ} \mathrm{E}$. The heat flow data are tabulated and analyzed by Martinez and Cochran [1989].

depression in every segment except for Segment A, located just south of the triple junction (Figures 11a and $11 \mathrm{~b}$ ).

[50] Although the amount of extension is continuous along the axis, melt delivery to the surface is not two-dimensional but rather melt generated under the axis within a segment is focused to a specific location within that segment. Strong focusing of melt within segments is observed at mature oceanic slow-spreading rate mid-ocean ridges such as the Mid-Atlantic Ridge [e.g., Lin et al., 1990; Detrick et al., 1995; Magde et al., 2000]. Apparently this focusing mechanism is also operative within a continental rift during the earliest stages of magmatic extension.

[51] A deep is mapped on the floor of the axial depression between the two volcanoes in each segment (Figures 11a and 11b). These are sediment-floored depressions a few to $10 \mathrm{~km}$ across, that are about $200 \mathrm{~m}$ deeper than the surrounding seafloor. Conrad Deep, near $27^{\circ} \mathrm{N}$ in Segment B (Figure 11a) is highly elongated along a $\mathrm{N}^{\circ} 0^{\circ} \mathrm{E}$ trend [Cochran et al., 1986], parallel to the Gulf of Aqaba trend. The other deeps are not as well mapped, but appear to be amorphous. The origin of these deeps is unclear. Gaulier et al. [1988] noted that ESP profiles centered over the axial depression generally gave lower crustal velocities than the adjacent portion of the main trough, which they attribute to extensive crustal fracturing. They also argue that a $6.4-6.6 \mathrm{~km} / \mathrm{s}$ layer making up the lower crust on their ESP 14 centered at Conrad Deep results from basic intrusions into this fractured crust [Gaulier et al., 1988].

[52] Pautot et al. [1984] mapped a small volcano within Shaban Deep in Segment D and recovered a fragment of tholeiitic ferrobasalt from it [Maury et al., 1985]. This volcano covers an area of about $8 \mathrm{~km}$ by $2 \mathrm{~km}$ and is elongated along a $N 150^{\circ} \mathrm{E}$ trend, parallel to the trend of the axis. It reaches a depth of $860 \mathrm{~m}$, about $630 \mathrm{~m}$ above the adjacent seafloor [Pautot et al., 1984]. Flanking volcanoes on the edge of the axial depression, similar to those observed at other segments, are also present within Segment D (Figures 11a and 11b). The dipolar magnetic anomalies from these three volcanoes merge together to form a NE-SW-trending linear high-low pair (Figure 6).

[53] The Shaban Deep volcano is the first expression of axial volcanism in the northern Red Sea rift. The first melt under the axis ascended along throughgoing faults to produce the matched volcanoes flanking the axial depression, perhaps with some intrusion into the lower crust beneath the axis. However, very quickly, the increased amounts of magma, repeated intrusions and perhaps also increasing shallow isotherms create a situation where magma can ascend directly to the surface through the pre-existing crust rather than along the conduits provided by the large block-bounding faults. Since all of the volcanic magnetic anomalies show normal magnetization (Figure 6), this process 
took less than $780 \mathrm{kyr}$ in Segment D, although it is not possible with the present data to say exactly how much time the transformation to axial volcanic extension takes to occur.

[54] The model proposed here for the development of the northern Red Sea involves an extended period of rifting and extension of continental crust prior to the development of a magmatic axis. As a result, the continental crust within the water-covered Red Sea is less than $10 \mathrm{~km}$ thick. There is no evidence of a zone of exhumed mantle such as is observed at the amagmatic Galicia margin [e.g., Boillot et al., 1987, 1988; Krawczyk et al., 1996; Chian et al., 1999]. The transition to a magmatic axis is just beginning in the northern Red Sea. In the central Red Sea $\left(\sim 21^{\circ} \mathrm{N}-23^{\circ} 30^{\prime} \mathrm{N}\right)$, where more extension has occurred, discrete seafloor spreading cells have developed and are propagating along axis. However, the majority of the width of the sea is underlain by quite thin continental crust. In the southern Red Sea, with additional extension, the individual cells have grown together to form a continuous spreading axis. The age to which seafloor-spreading magnetic anomalies extend in the southern Red Sea varies quasiperiodically along the axis [Roeser, 1975] strongly suggesting that the active spreading axis developed as a series of isolated cells that grew together to form a continuous axis [Cochran, 1983].

\section{Alternative Models for Red Sea Evolution}

[55] The model developed above appears to explain the entire set of available observations. The major shortcoming of the model is the lack of seismic reflection data that image the structure of the top of the crust to verify the sets of rotated fault blocks that are inferred to occupy the main trough. This is, however, not the only model that has been proposed for the development of the Red Sea. Very different models have been proposed that emphasize certain subsets of the data, particularly seismic refraction results.

\subsection{Oceanic Main Trough Model}

[56] Gaulier et al. [1988] and LePichon and Gaulier [1988] proposed a model for the development of the northern Red Sea in which the distribution of oceanic crust is defined by crustal seismic velocity. Gaulier et al. [1988] presented the results of an extensive ESP seismic refraction experiment in the northern Red Sea. The ESP lines form two traverses from near the Egyptian coast to the axis of the Red Sea with the individual profiles oriented NW-SE along-strike of the sea. The northern transect extends seaward from about $26^{\circ} 45^{\prime} \mathrm{N}$ within Segment B along the profile shown in Figure 7. The southern transect is centered within Segment D. All of the profiles show very thin crust in the range of $5.1-8.3 \mathrm{~km}$ thick and a very uniform Moho depth [Gaulier et al., 1988]. However, the traverses give very different crustal velocities. The northern set shows relatively low crustal velocities $(5.5-6.4 \mathrm{~km} / \mathrm{s})$. The southern set, on the other hand, shows a main crustal layer with higher velocities in the range of $6.45-6.8 \mathrm{~km} / \mathrm{s}$.

[57] Gaulier et al. [1988] interpreted the higher velocities in the southern transect as being diagnostic of oceanic crust. LePichon and Gaulier [1988] hypothesized that seafloor spreading began in the northern Red Sea at about $13 \mathrm{Ma}$ as the result of an acceleration in the motion between Africa and Arabia. LePichon and Gaulier [1988] argue that an abrupt boundary from oceanic crust in the south to very thin continental crust in the north could result from the northern area being within a broad Levant shear zone until the end of the Miocene when motion became centered on present narrower transform. The southern boundary of this hypothesized shear zone extends roughly along AZ3 near the Brothers Islands to the axis of the sea and then north to reach the coast near $28^{\circ} \mathrm{N}, 35^{\circ} 10^{\prime} \mathrm{E}$ (Figure 3).

[58] Cochran and Martinez [1988] undertook a detailed critique of this model. There are several difficulties. First, Rihm et al. [1991] presented results of three unreversed OBS seismic refraction lines from the eastern Red Sea centered near $\left(26^{\circ}\right.$ $\left.7.5^{\prime} \mathrm{N}, 35^{\circ} 56^{\prime} \mathrm{E}\right),\left(27^{\circ} \mathrm{N}, 35^{\circ} 24^{\prime} \mathrm{E}\right)$, and $\left(27^{\circ} 25^{\prime} \mathrm{N}\right.$, $\left.35^{\circ} 7^{\prime} \mathrm{E}\right)$. Mantle arrivals were not obtained on any of these lines, but all three gave upper crustal $\mathrm{P}$ wave velocities of $5.8-6.2 \mathrm{~km} / \mathrm{s}$, velocities assumed by Gaulier et al. [1988] as indicative of continental crust. Two of the three refraction lines are, however, in areas that LePichon and Gaulier [1988] hypothesize are floored by oceanic crust.

[59] Also, the ocean-continent boundary proposed by LePichon and Gaulier [1988] is not apparent in the geophysical data (Figures 3, 4a, 4b, 5, and 6). Not only is the proposed boundary not evident, but the bathymetry and the nature of the geophysical anomalies remain unchanged across the proposed boundary. On both sides of the proposed boundary the bathymetry consists of terraces stepping down to the axial depression with free-air gravity highs 
on the seaward edge of the terraces. The magnetic anomalies throughout the entire area are dipolar anomalies indicating isolated, normally magnetized sources. In particular, the nature of the axial depression and the relationship of volcanoes to the axial deep remain constant throughout the entire area north of Mabahiss Deep.

[60] Finally, the change in crustal velocities between the northern and southern sets of northern Red Sea ESP experiments [Gaulier et al., 1988] corresponds to a north-south change in the nature of the basement rocks observed onshore in Egypt. The Eastern Desert of Egypt has been divided into three sections on the basis of the type of Precambrian basement rock exposed in the red Sea hills [Stern and Hedge, 1985]. The north Eastern Desert basement "is composed of $70 \%-80 \%$ granite, granodiorite and allied plutonic rocks and is weakly deformed" [Stern et al., 1984, p. 168]. In contrast, the central Eastern Desert basement consists mainly of mafic metavolcanics, gabbros, ultramafic rocks and associated metasedimentary rocks. Greiling et al. [1988, p. 180] describe the central Eastern Desert as "made up almost exclusively of ophiolitic mélange and associated rocks, together with subordinate molasse-type sediments and late tectonic volcanics and intrusives". Stern et al. [1984] describe the boundary between the northern and central Eastern Desert as a "major structural discontinuity" and state "missing in the basement of the north Eastern desert are the ophiolitic ultramafics and low-K pillowed tholeiites, mélanges, banded $\mathrm{Fe}$ formation and northwesttrending shears characteristic of the central Eastern Desert". The boundary between the two provinces is located between Safaga $\left(26^{\circ} 40^{\prime} \mathrm{N}\right.$ and Quseir $\left(26^{\circ} 05^{\prime} \mathrm{N}\right)$. These observations suggest that the north-to-south change in the basement velocity structure in the northern Red Sea, interpreted by LePichon and Gaulier [1988] as a change from continental to oceanic crust, is actually a change between two very different, but both continental, types of prerift basement rocks.

\subsection{Asymmetric Pull-Apart Model}

[61] Another series of papers [Rihm et al., 1991; Makris and Rihm, 1991; Makris and Henke, 1992; Rihm and Henke, 1998] develop a model for the evolution of the Red Sea also based on seismic refraction results. They assumed, as did LePichon and Gaulier [1988], that the higher velocity crustal velocities observed between $25^{\circ} \mathrm{N}$ and $26^{\circ} \mathrm{N}$ in the western Red Sea demonstrate the presence of oceanic crust in that area. They hypothesize that this crust formed in pull-apart basins. This model assumes that the earliest motion along the Red Sea rift was left-lateral strike slip along reactivated Pan-African sutures and fault zones. Sinuousness in this plate boundary created "proto-pull-apart basins". These authors assume that, at about $22 \mathrm{Ma}$, a burst of volcanic activity accompanied a reorganization of plate motion in which separation accelerated and the direction of motion shifted to be parallel to the present Dead Sea transform. The increased opening and availability of magma led to formation of oceanic crust in the nascent pull-apart basins, which widened and coalesced. During the time that pull-apart basins formed along the western margin of the Red Sea, the eastern margin is assumed to have been extended through rotation of large crustal fault blocks forming a broad continental margin that contrasts greatly with the hypothesized abrupt western margin [Makris and Rihm, 1991; Rihm and Henke, 1998]. For unspecified reasons, the nature of extension changed at about $5 \mathrm{Ma}$, when the Red Sea developed it present extensional axis delineated by the axial depression and seafloor spreading began to propagate north within this axis from the southern Red Sea.

[62] Makris and Rihm [1991] argue that major development of oceanic pull-apart basins in the northern Red Sea began at $18-20 \mathrm{Ma}$ as the result of "intensified rifting" accompanied by "pronounced magmatism" in the northern Red Sea. They supported their assertion of intense magmatic activity in the northern Red Sea by a histogram in which they divide the Red Sea into three sections (south, central and north) and for each section show the percentage of magmatic events in each sector during three time slices (30-26 Ma, 26-22 Ma, and 22-18 Ma). This histogram was interpreted to show a wave of volcanism moving north in the Red Sea. There are a number of problems with this argument. First, the histogram is deceptive because it looks at the percentage of events and not the total number of magmatic events within each area during each time slice. The southern Red Sea was subjected to very intense magmatism [e.g., Mohr, 1978; Coleman et al., 1975, 1983; Pallister, 1987; Coleman and McGuire, 1988] totaling thousands of individual events. However, Oligocene and Miocene volcanism in the northern Red Sea is limited to only a few scattered minor flows and dikes in the lowermost syn-rift 
sediments [e.g., Plaziat et al., 1998b; Bosworth and McClay, 2001] which does not represent the "pronounced magmatism" claimed by Makris and Rihm [1991].

[63] Even more crucially, the histogram is based primarily on $\mathrm{K}-\mathrm{Ar}$ dating. More recent and more accurate ${ }^{40} \mathrm{Ar} /{ }^{39} \mathrm{Ar}$ dating demonstrates that although volcanism in Ethiopia, Afar and southern Yemen related to the Afar plume began around $30 \mathrm{Ma}$ [e.g., Zumbo et al., 1995a; Hofmann et al., 1997; Coulie et al., 2003], volcanism in the southern Red Sea occurred primarily at 24-21 Ma [Sebai et al., 1991; Feraud et al., 1991], contemporaneous with volcanism in the northern Red Sea [e.g., Bartov et al., 1980; Eyal et al., 1981; Plaziat et al., 1998b; Bosworth and McClay, 2001]. Magmatic activity related to rifting thus was simultaneous and corresponds to the onset of rifting throughout the length of the Red Sea.

[64] A crucial assumption of the asymmetric pullapart model of Makris and Rihm [1991] and Rihm and Henke [1998] is an early stage of strike slip motion parallel to the present rift trend. Bosworth and McClay [2001] carefully reviewed outcrop data from the Gulf of Suez and conclude that "strike-slip kinematic indicators have not been found along major block-bounding faults of the southern, central or northern Gulf of Suez" and "all significant populations of fault kinematic indicators, whether from major bounding fault complexes or smaller-scale faults, and of all ages, are compatible with ENE-WSW to NNE-SSW extension" [Bosworth and McClay, 2001, p. 597] In addition, the presence of 21-24 Ma dikes parallel to the present rift trend [Bartov et al., 1980; Eyal et al., 1981; Sebai et al., 1991] along the northern Red Sea margins demonstrates that the stress field at the time of rift initiation was normal to the present overall trend of the rift (i.e., $\mathrm{N} 60^{\circ} \mathrm{E}$ and not $\mathrm{N} 15^{\circ} \mathrm{E}$ ) (W. Bosworth, personal communication, 2004).

[65] Rihm et al. [1991] show a crustal velocity of $6.5 \mathrm{~km} / \mathrm{s}$ on the seismic section that they display from the hypothesized area of oceanic crust in northern Red Sea. This velocity is consistent with crustal velocities of $6.45-6.8$ on seismic lines in the same area reported by Gaulier et al. [1988]. Makris and Rihm [1991] hypothesize a second region of oceanic crust, also generated in pull-apart basins along the African margin between $19^{\circ} \mathrm{N}$ and $22^{\circ} \mathrm{N}$ in the central Red Sea. The seismic lines interpreted by Egloff et al. [1991] and Makris and Rihm [1991] as oceanic off of Sudan display a thin
$(<5 \mathrm{~km})$ crust with crustal velocities of 4.6-6.4 $\mathrm{km} / \mathrm{s}$. A nearby seismic refraction line showing a $12 \mathrm{~km}$ thick crust in which lower crustal velocities reach $6.8 \mathrm{~km} / \mathrm{s}$ was interpreted as thinned continental crust. Rihm et al. [1991], Egloff et al. [1991], and Makris and Rihm [1991] never state their criteria for recognizing crust as oceanic, but the observations above suggest that their primary criterion is crustal thickness, independent of velocity. This is also suggested by the fact that their maps indicate that oceanic crust extends into the region of the northern ESP transect of Gaulier et al. [1988], which also displayed low crustal velocities and was interpreted by LePichon and Gaulier [1988] as thin continental crust.

[66] The asymmetric pull-apart rifting model for the northern Red Sea developed by Makris and Rihm [1991] and Rihm and Henke [1998] is not supported by the available geophysical and geological data. As with the LePichon and Gaulier [1988] model, the proposed area of oceanic crust (roughly $20-70 \mathrm{~km}$ off the African coast between $24^{\circ} \mathrm{N}$ and $27^{\circ} \mathrm{N}$ ) is not apparent in either the bathymetry (Figure 3 ) nor in the gravity nor magnetic anomalies (Figures $4 \mathrm{a}, 5$, and 6). In contrast, Mabahiss Deep, which, although not discussed at all in this set of papers or shown on any of their maps, is a pull-apart basin floored by basalt [Guennoc et al., 1988; Coutelle et al., 1991], has a prominent bathymetric expression (Figures 3 and $11 \mathrm{~b}$ ) and large potential field anomalies (Figures 4a, 5, 6, and 12b). It is, however, located on the eastern side of the Red Sea and thus is not compatible with the Makris and Rihm [1991] model.

[67] Makris et al. [1991] present a 2-D model of Bouguer gravity anomalies in the northernmost Red Sea that appears to show a very asymmetric structure with much more rapid crustal thinning on the African side and higher density oceanic crust within the Red Sea. Makris and Rihm [1991] state that this model verifies their hypothesis for the development for the Red Sea. Unfortunately, the profile modeled by Makris et al. [1991] passes through the southernmost Gulf of Suez and crosses into the Red Sea across the Dead Sea/Suez transform margin rather than the rifted African margin. The rapid change in crustal thickness is due to crossing a transform boundary where a large change in crustal thickness is expected because of the greatly differing amounts of extension on either side of this boundary [e.g., Steckler et al., 1988]. The contention of Makris and Rihm [1991] that the 
gravity modeling of Makris et al. [1991] supports their model is not correct.

[68] Makris and Rihm [1991] note that the northern two heat flow profiles of Martinez and Cochran [1989] are asymmetric with the heat flow peak located to the west of the center line of the Red Sea (Figure 17) and argue "the heat flow is not controlled by simple stretching and symmetrical extension along a central axis. It is aligned along NNE-SSW (Aqaba-trend) oriented fractures of enechelon distribution" [Makris and Rihm, 1991, p. 450]. Makris and Rihm [1991] did not show bathymetry profiles to accompany the Martinez and Cochran [1989] profiles. The bathymetry clearly shows that the heat flow maximum is over the axial depression in each profile (Figure 17). The northern profiles are offset to the west because the axial depression runs diagonally across the main trough from Mabahiss Deep to the Suez triple junction (Figure 3).

\section{Summary and Conclusions}

[69] The continental margins of the northern Red Sea are abrupt and faulted with a narrow coastal plain and continental shelf. A scarp marks the seaward edge of the shelf along both margins. Seaward of the shelf-edge scarps, the bathymetry steps down in a series of terraces $20-30 \mathrm{~km}$ wide and often fault-bounded, to a $15-30 \mathrm{~km}$ wide axial depression at a depth of 1100-1200 m. Geophysical data implies that the terraces are a subdued expression of the basement structure, which consists of a series of large rotated fault blocks.

[70] The rift is segmented along-strike by throughgoing accommodation zones spaced at 40-60 km intervals along the rift. In the main trough, the accommodation zones separate sets of crustal fault blocks and, as a result, truncate or offset riftparallel bathymetric and gravity features. The segmentation is most obvious at the axis. The axial depression consists of a series of discrete depressions offset from each other and separated by slightly shallower areas corresponding to the accommodation zones. Where accommodation zones can be identified onshore in Egypt, there is a correspondence between the offshore segmentation and the onshore rift segmentation.

[71] Seismic refraction studies show that, at distances of greater than about $20 \mathrm{~km}$ from the margin, the crust within the northern Red Sea is thin $(5-8.5 \mathrm{~km})$. The Moho is at a relatively constant depth of $13-14.5 \mathrm{~km}$. These observa- tions imply that extension was distributed across the entire width of the sea for much of its development. Extension appears to have occurred by rotation of the large crustal blocks underlying the main trough along listric faults that soled out into a zone of plastic creep, resulting in the observed flat Moho. The presence of fault scarps bounding the main trough terraces in places suggests that the large block-bounding faults are still active. However, recent deformation and extension appear to be primarily concentrated within the axial depression where the sediments are highly deformed and faulted. Analysis of heat flow data [Buck et al., 1988; Martinez and Cochran, 1989] also requires that extension has become centered at the axial depression over the last few million years.

[72] The axial depression trends at $\sim \mathrm{N} 140^{\circ} \mathrm{E}$, or at an angle of about $10^{\circ}$ to the $\mathrm{N} 150^{\circ} \mathrm{E}$ trend of the rift. As a result, it cuts across the main trough from Mabahiss Deep, located on the eastern side of the sea, to the Gulf of Suez on the western side (Figure 3). The axial depression is thus closer to orthogonal to the present-day opening direction than is the overall rift. The water depth within the axial depression increases and the axial free-air gravity anomaly becomes more negative away from accommodation zones toward a small deep located within each segment. Deeps are small, generally sediment-floored depressions that are a few kilometers across and about $200 \mathrm{~m}$ deeper than the adjacent seafloor. With the exception of Segment A, immediately adjacent to the Suez triple junction, a pair of small volcanoes flanks the deep within each segment. These volcanoes are located on the seaward edge of the first terrace flanking the axial depression on each side. All of the volcanoes are normally magnetized and are therefore younger than 780 kyr. They may be much younger. A volcano is also located on the floor of the axial depression within Shaban Deep in Segment D (Figures 3, 11a, and 11b).

[73] These observations allow development of a model for the development of an oceanic spreading center within a previously amagmatically extending continental rift. The Gulf of Suez was the northern continuation of the Red Sea rift until the establishment of the Dead Sea transform cut it off in the mid Miocene [Steinitz et al., 1978; Eyal et al., 1981; Steckler and ten Brink, 1986]. The Gulf of Suez consists of sets of rotated crustal fault blocks separated by accommodation zones [Moustafa, 1976; Colletta et al., 1988], as found in 
the Red Sea. However, the Gulf of Suez has an asymmetric structure, with all blocks within a segment rotated in the same direction [e.g., Colletta et al., 1988; Steckler et al., 1988; Patton et al., 1994], suggesting that northern Red Sea also had such an asymmetric structure until at least the mid-Miocene. More than $100 \mathrm{~km}$ of extension has occurred in the northern Red Sea since the establishment of the Dead Sea Rift [Freund et al., 1968, 1970]. Geophysical data from the northern Red Sea indicate that this extension has occurred in a manner similar to the earlier extension in the Gulf of Suez by mechanical rotation of large fault blocks, accompanied by ductile flow in the lower crust. This extension was distributed across the rift and produced both an extremely thinned crust and a nearly flat Moho (Figure 7).

[74] The present symmetric Red Sea rift, with sets of fault blocks stepping down to an axial depression is, however, very different from the rift structure observed in the Gulf of Suez. At some point in its evolution, the Red Sea developed a symmetric structure and extension became largely concentrated near the axis. Although these two events cannot be demonstrated to have been simultaneous, it is logical to link them. The development of a symmetric Red Sea with an axial depression has occurred relatively recently. If the top of the evaporites is assumed to have been a level surface at the end of evaporite deposition near the Miocene-Pliocene boundary ( $\sim 5 \mathrm{Ma}$ ), then the relative subsidence of the axis has occurred since then. Similarly, quantitative modeling of heat flow data [Buck et al., 1988; Martinez and Cochran, 1989] requires that extension became concentrated at the axis within the last few million years. It is unclear from the bathymetry and gravity data whether the establishment of a symmetric basin was accompanied by the generation of a new system of faults, so that the main block-bounding faults now all dip toward the axis, or whether all faults within a segment still dip in the same direction. Seismic data that could address this question is not available. The edge of the continental shelf on both margins does appear to be formed by a large normal fault dipping toward the axis. The faults bounding the axial depression also appear to consistently dip toward the axis.

[75] Concentration of extension near the axis has resulted in rapid lithospheric thinning and the generation of melt. Melt generated within a segment appears to be focused to a specific location within the segment where it ascends along the faults bounding the axial depression. This has resulted in the construction of a pair of volcanoes flanking the axial depression near the deep within each segment. The observation of a volcano at the axis within Shaban Deep suggests that, relatively rapidly, the melt is able to ascend vertically under the axis. With continued extension and magmatism, the small volcano in Shaban Deep can be expected to develop into a seafloor spreading cell, such as those observed in the central Red Sea [Pautot, 1983; Bicknell et al., 1986]. The continuous spreading axis in the southern Red Sea appears to have formed by the growth and coalescence of the original individual cells [Roeser, 1975; Miller et al., 1985].

\section{Acknowledgments}

[76] This work was supported by National Science Foundation grant OCE-9819563. I would like to thank Bill Bosworth, Garry Karner, and Michael Steckler for stimulating and instructive discussions. Bill Bosworth, the Associate Editor and an anonymous referee provided thorough and thoughtful reviews that were extremely valuable. The GMT software package [Wessel and Smith, 1998] was used extensively in data analysis and the preparation of figures. This is LDEO contribution 6711 .

\section{References}

Backer, H., and M. Schoell (1972), New deeps with brines and metaliferous sediments in the Red Sea, Nature Phys. Sci., 240, 153-158.

Backer, H., K. Lange, and H. Richter (1975), Morphology of the Red Sea Central Graben between Subair Islands and Abul Kizaan, Geol. Jahrb., D13, 79-123.

Barakat, H., and P. M. Miller (1984), Geology and petroleum exploration, Safaga Concession, northern Red Sea, Egypt, paper presented at Seventh Exploration Seminar, Egypt. Gen. Pet. Corp., Cairo, Egypt.

Bartov, Y., G. Steinitz, M. Eyal, and Y. Eyal (1980), Sinistral movement along the Gulf of Aqaba-Its age and relation to opening of the Red Sea, Nature, 285, 220-221.

Bicknell, J. D., K. C. Macdonald, S. P. Miller, P. F. Lonsdale, and K. Becker (1986), Tectonics of the Nereus Deep, Red Sea: A deep tow investigation of a site of initial rifting, Mar. Geophys. Res., 8, 131-148.

Blank, H. R. (1977), Aeromagnetic and geologic study of Tertiary dikes and related structures on the Arabian margin of the Red Sea, in Red Sea Research 1970-1975, Miner. Resour. Bull. 2, pp. G1-G27, Dir. Gen. of Miner. Resour., Jeddah, Saudi Arabia.

Boillot, G., et al. (1987), Tectonic denudation of the upper mantle along passive margins: A model based on drilling results (ODP leg 103, western Galicia margin, Spain), Tectonophysics, 132, 335-342.

Boillot, G., J. Girardeau, and J. Kornprobst (1988), Rifting of the Galicia margin: Crustal thinning and emplacement of mantle rocks on the seafloor, Proc. Ocean Drill. Program Sci. Results, 103, 741-755. 
Bonatti, E. (1985), Punctiform initiation of seafloor spreading in the Red Sea during transition from a continental to an oceanic rift, Nature, 316, 33-37.

Bonatti, E., and M. Seyler (1987), Crustal underplating and evolution in the Red Sea rift: Uplifted gabbro/gneiss crustal complexes on Zabargad and Brothers Islands, J. Geophys. Res., 92, 12,803-12,821.

Bonatti, E., P. R. Hamlyn, and G. Ottonello (1981), The upper mantle beneath a young oceanic rift: Peridotites from the island of Zabargad (Red Sea), Geology, 9, 474-479.

Bonatti, E., et al. (1983), Zabargad (St. John's) Island: An uplifted fragment of sub-Red Sea lithosphere, J. Geol. Soc. London, 140, 677-690.

Bonatti, E., P. Colantoni, B. Della Vedova, and M. Taviani (1984), Geology of the Red Sea transitional zone $\left(22^{\circ} \mathrm{N}-\right.$ $\left.25^{\circ} \mathrm{N}\right)$, Oceanol. Acta, 7, 385-398.

Bosworth, W. (1985), Geometry of propagating continental rifts, Nature, 316, 625-627.

Bosworth, W. (1994), A model for the three-dimensional evolution of continental rift basins, north-east Africa, Geol. Rundsch., 83, 671-688.

Bosworth, W., and K. McClay (2001), Structural and stratigraphic evolution of the Gulf of Suez Rift, Egypt: A synthesis, in Peri-Tethys Memoir 6: Peri-Thetyan Rift/Wrench Basins and Passive Margins, edited by P. A. Ziegler et al., pp. 567-606, Mus. Natl. Histoire Nat., Paris.

Bosworth, W., J. Lambiase, and R. Keisler (1986), A new look at Gregory's Rift: The structural style of continental rifting, Eos Tran. $A G U, 67,577-583$.

Bosworth, W., M. Darwish, P. Crevello, M. Taviani, and S. Marshak (1996), Stratigraphic and structural evolution of Zabargad Island (Red Sea, Egypt) since the early Cretaceous, in Proceedings of the Third International Conference on the Geology of the Arab World, edited by S. A. Youssef, pp. 161-190, Cairo Univ., Cairo.

Bosworth, W., P. Crevello, R. D. Winn, and J. Steinmetz (1998), Structure, sedimentation, and basin dynamics during rifting of the Gulf of Suez and northwestern Red Sea, in Sedimentation and Tectonics in Rift Basins: Red Sea-Gulf of Aden, edited by B. H. Purser and D. W. J. Bosence, pp. 77-96, CRC Press, Boca Raton, Fla.

Bown, J. W., and R. S. White (1994), Variation with spreading rate of oceanic crustal thickness and geochemistry, Earth Planet. Sci. Lett., 121, 435-449.

Buck, W. R., F. Martinez, M. S. Steckler, and J. R. Cochran (1988), Thermal consequences of lithospheric extension: Pure and simple, Tectonics, 7, 213-234.

Burgess, C. F., B. R. Rosendahl, S. Sander, C. A. Burgess, J. Lambiase, S. Derksen, and N. Meader (1988), The structural and stratigraphic evolution of Lake Tanganyika: A case study of Continental Rifting, in Triassic-Jurassic Rifting: Continental Breakup and the Origin of the Atlantic Ocean and Passive Margins, edited by W. Manspeizer, pp. 859881, Elsevier, New York.

Chase, R. L. (1969), Basalt from the axial trough of the Red Sea, in Hot Brines and Recent Heavy Metal Deposits in the Red Sea: A Geochemical and Geophysical Account, edited by E. T. Degens and D. A. Ross, pp. 122-128, Springer, New York.

Chian, D., K. E. Louden, T. A. Minshull, and R. B. Whitmarsh (1999), Deep structure of the ocean-continent transition in the southern Iberia Abyssal plain from seismic refraction profiles: Ocean Drilling Program (Legs 149 and 173) transect, J. Geophys. Res., 104, 7443-7462.

Chu, D., and R. G. Gordon (1998), Current plate motions across the Red Sea, Geophys. J. Int., 135, 313-328.
Cochran, J. R. (1983), A model for the development of the Red Sea, AAPG Bull., 67, 41-69.

Cochran, J. R., and F. Martinez (1988), Evidence from the northern Red Sea on the transition from continental to oceanic rifting, Tectonophysics, 153, 25-53.

Cochran, J. R., F. Martinez, M. S. Steckler, and M. A. Hobart (1986), Conrad Deep: A new Northern Red Sea Deep. Origin and implications for continental rifting, Earth Planet. Sci. Lett., 78, 18-32.

Cochran, J. R., J. M. Gaulier, and X. LePichon (1991), Crustal structure and the mechanism of extension in the northern Red Sea: Constraints from gravity anomalies, Tectonics, 10, 1018-1037.

Coleman, R. G. (1984), The Red Sea: A small ocean basin formed by continental extension and seafloor spreading, in Proceedings of the 27th International Geological CongressInvited Papers, vol. 23, pp. 93-121, E. J. Brill USA, Boston, Mass.

Coleman, R. G., and A. V. McGuire (1988), Magma systems related to the Red Sea system, Tectonophysics, 150, 77-100.

Coleman, R. G., M. Tatsumoto, D. G. Coles, C. E. Hedge, and R. E. Mays (1973), Red Sea basalts, Eos Trans. AGU, 54, $1001-1002$.

Coleman, R. G., R. J. Fleck, C. E. Hodge, and E. D. Ghent (1975), The volcanic rocks of southwest Saudi Arabia and the opening of the Red Sea, in Red Sea Research 19701975, Miner. Resour. Bull. 2, pp. D1-D30, Dir. Gen. of Miner. Resour., Jeddah, Saudi Arabia.

Coleman, R. G., R. T. Gregory, and G. F. Brown (1983), Cenozoic volcanic rocks of Saudi Arabia, U.S. Geol. Surv Open File Rep., 83-788, 82 pp.

Colletta, B., P. LeQuellec, J. Letouzey, and I. Moretti (1988), Longitudinal evolution of the Suez rift structure (Egypt), Tectonophysics., 153, 221-233.

Coulie, E., X. Quidelleur, P. Y. Gillot, V. Courtillot, J. C. Lefevre, and S. Chiesa (2003), Comparative K-Ar and Ar/ Ar dating of Ethiopian and Yemenite Oligocene volcanism: Implications for timing and duration of the Ethiopian traps, Earth Planet. Sci. Lett., 206, 477-492.

Courtillot, V. E. (1982), Propagating rifts and continental breakup, Tectonics, 1, 239-250.

Coutelle, A., G. Pautot, and P. Guennoc (1991), The structural setting of the Red Sea axial valley and deeps: Implications for crustal thinning processes, Tectonophysics, 198, 395-409.

Crane, K., and E. Bonatti (1987), The role of fracture zones during early Red Sea rifting: Structural analysis using Space Shuttle radar and LANDSAT imagery, J. Geol. Soc. London, 144, 407-420.

Daggett, P. H., P. Morgan, F. K. Boulos, S. F. Hennin, A. A. El-Sherif, A. A. El-Sayed, N. Z. Basta, and Y. S. Melek (1986), Seismicity and active tectonics of the Egyptian Red Sea margin and the northern Red Sea, Tectonophysics, $125,313-324$.

Davison, I., et al. (1994), Geological evolution of the southeastern Red Sea rift margin, Republic of Yemen, Geol. Soc. Am. Bull., 106, 1474-1493.

Degens, E. T., and D. A. Ross (1969), Hot Brines and Recent Heavy Metal Deposits in the Red Sea, 600 pp., Springer, New York.

Detrick, R. S., H. D. Needham, and V. Renard (1995), Gravity anomalies and crustal thickness variations along the MidAtlantic Ridge between $33^{\circ} \mathrm{N}$ and $40^{\circ} \mathrm{N}$, J. Geophys. Res., 100, 3767-3787.

Dixon, T. H., R. J. Stern, and I. M. Hussein (1987), Control of Red Sea rift geometry by Precambrian structures, Tectonics, $6,551-572$. 
Ebinger, C. J. (1989a), Geometric and kinematic development of border faults and accommodation zones, Kivu-Rusizi Rift, Africa, Tectonics, 8, 117-134.

Ebinger, C. J. (1989b), Tectonic development of the western branch of the East African rift system, Bull. Geol. Soc. Am., 101, 885-903.

Egloff, F., R. Rihm, J. Makris, Y. A. Izzeldin, M. Bobsien, K. Meier, P. Junge, T. Noman, and W. Warsi (1991), Contrasting structural styles of eastern and western margins of the southern Red Sea: The 1988 Sonne experiment, Tectonophysics, 198, 329-353.

El Shazly, E. M., and J. G. Saleeb (1979), Genesis of peridotite in St. John's Island, Red Sea, and its relation to the metasomatism of the ultrabasic rocks, Egypt. J. Geol., 23, 17-36.

El Shazly, E. M., G. S. Saleeb Roufaiel, and N. Zaki (1974), Quaternary Basalt in Saint John's Island, Egypt. J. Geol., 18(2), 137-148.

Eyal, M., Y. Eyal, Y. Bartov, and G. Steinitz (1981), The tectonic development of the western margin of the Gulf of Elat (Aqaba) Rift, Tectonophysics, 80, 39-66.

Feraud, G., V. Zumbo, A. Sebai, and H. Bertrand (1991), ${ }^{40} \mathrm{Ar} /{ }^{39} \mathrm{Ar}$ age and duration of tholeiitic magmatism related to the early opening of the Red Sea Rift, Geophys. Res. Lett., 18(2), 195-198.

Freund, R., I. Zak, and Z. Garfunkel (1968), Age and rate of the sinistral movement along the Dead Sea Rift, Nature, 220, $253-255$.

Freund, R., Z. Garfunkel, I. Zak, M. Goldberg, T. Weissbrod, and B. Derin (1970), The shear along the Dead Sea Rift, Philos. Trans. R. Soc. London, Ser. A, 267, 107-130.

Garfunkel, Z., A. Ginzburg, and R. C. Searle (1987), Fault pattern and mechanism of crustal separation along the axis of the Red Sea from side scan sonar (GLORIA) data, Ann. Geophys., 5B, 187-200.

Gaulier, J. M., X. LePichon, N. Lyberis, F. Avedik, L. Geli, I. Moretti, A. Deschamps, and S. Hafez (1988), Seismic study of the crustal thickness, Northern Red Sea and Gulf of Suez, Tectonophysics, 153, 55-88.

Girdler, R. W., and T. C. Southren (1987), Structure and evolution of the northern Red Sea, Nature, 330, 716-721.

Greiling, R. O., M. F. El Ramly, H. El Arhal, and R. J. Stern (1988), Tectonic evolution of the northwestern Red Sea margin as related to basement structure, Tectonophysics, 153, $179-191$

Guennoc, P., G. Pautot, and A. Coutelle (1988), Surficial structures of the northern Red Sea axial valley from $23^{\circ} \mathrm{N}$ to $28^{\circ} \mathrm{N}$ : Time and space evolution of neo-oceanic structures, Tectonophysics, 153, 1-23.

Guennoc, P., G. Pautot, M.-F. Le Quentric, and A. Coutelle (1990), Structure of an early oceanic rift in the northern Red Sea, Oceanol. Acta, 13, 145-155.

Hoang, C. T., and M. Taviani (1991), Stratigraphic and tectonic implications of uranium-series-dated coral reefs from uplifted Red Sea islands, Quat. Res., 35, 264-273.

Hofmann, C., V. Courtillot, G. Feraud, P. Rochette, G. Yirgu, E. Ketefo, and R. Pik (1997), Timing of the Ethiopian flood basalt event and implications for plume birth and global change, Nature, 389, 838-841.

Hughes, G. W., O. Varol, and Z. R. Beydoun (1991), Evidence for middle Oligocene rifting of the Gulf of Aden and for late Oligocene rifting of the southern Red Sea, Mar. Petrol. Geol., 8, 354-358.

Hughes, G. W., D. Perincek, D. J. Grainger, A.-J. Abu-Bshait, and A.-R. M. Jared (1999), Lithostratigraphy and depositional history of part of the Midyan region, northwestern Saudi Arabia, Geo-Arabia, 4, 503-542.
Izzeldin, A. Y. (1989), Transverse structures in the central part of the Red Sea and implications on early stages of oceanic accretion, Geophys. J., 96, 117-129.

Jarrige, J. J., P. Ott d'Estevou, P. F. Burollet, C. Montenat, J. P. Richert, and J. P. Thiriet (1990), The multistage tectonic evolution of the Gulf of Suez and northern Red Sea continental rift from field observations, Tectonics, 9, 441-465.

Jestin, F., P. Huchon, and J. M. Gaulier (1994), The Somalia plate and the East African Rift System: Present-day kinematics, Geophys. J. Int., 116, 637-654.

Joffe, S., and Z. Garfunkel (1987), Plate kinematics of the circum Red Sea-A re-evaluation, Tectonophysics, 141, $5-23$.

Kebeasy, R. M. (1990), Seismicity, in The Geology of Egypt, edited by R. Said, pp. 51-59, A. A. Balkema, Brookfield, $\mathrm{Vt}$

Knott, S. T., E. T. Bunce, and R. L. Chase (1966), Red Sea seismic reflection studies, in The World Rift System, Pap. 66-14, pp. 78-97, Geol. Surv. of Can., Ottawa, Ontario, Canada.

Krawczyk, C. M., T. J. Reston, M. O. Beslier, and G. Boillot (1996), Evidence for detachment tectonics on the Iberia abyssal Plain rifted margin, Proc. Ocean Drill. Program Sci. Results, 149, 603-615.

LePichon, X., and J.-M. Gaulier (1988), The rotation of Arabia and the Levant fault system, Tectonophysics, 153, 271-294.

Lin, J., G. M. Purdy, H. Schouten, J. C. Sempere, and C. Zervas (1990), Evidence from gravity data for focused magmatic accretion along the Mid-Atlantic Ridge, Nature, 344, 627-632.

Magde, L. S., A. H. Barclay, D. R. Toomey, R. S. Detrick, and J. A. Collins (2000), Crustal magma plumbing within a segment of the Mid-Atlantic Ridge, $35^{\circ} \mathrm{N}$, Earth Planet. Sci. Lett., 175, 55-67.

Makris, J., and C. H. Henke (1992), Pull-apart evolution of the Red Sea, J. Petrol. Geol., 15, 127-134.

Makris, J., and R. Rihm (1991), Shear-controlled evolution of the Red Sea: Pull apart model, Tectonophysics, 198, 441466.

Makris, J., B. Stoefen, R. Vees, A. Allem, M. Maamoun, and W. Shehata (1979), Deep seismic soundings in Egypt: Part II: Crust and upper mantle of the Red Sea Coast, internal report, 20 pp., Univ. of Hamburg, Hamburg, Germany.

Makris, J., A. Allam, T. Moktar, A. Basahel, G. A. Dehghani, and M. Bazari (1983), Crustal structure in the northwestern region of the Arabian Shield and its transition to the Red Sea, Bull. Fac. Sci. King Abdulaziz Univ., 6, pp. 435-447, King Abdulaziz Univ., Jeddah, Saudi Arabia.

Makris, J., C. H. Henke, F. Egloff, and T. Akamaluk (1991), The gravity field of the Red Sea and East Africa, Tectonophysics, 198, 369-381.

Martinez, F., and J. R. Cochran (1988), Structure and tectonics of the northern Red Sea: Catching a continental margin between rifting and drifting, Tectonophysics, 150, 1-32.

Martinez, F., and J. R. Cochran (1989), Geothermal measurements in the northern Red Sea: Implications for lithospheric thermal structure and mode of extension during continental rifting, J. Geophys. Res., 94, 12,239-12,266.

Maury, R. C., H. Bougault, A. Coutelle, P. Guennoc, J.-L. Joron, and G. Pautot (1985), Présence de ferrobasalte tholéiitique dans la fosse Jean-Charcot $\left(26^{\circ} 15^{\prime} \mathrm{N}, 35^{\circ} 22^{\prime} \mathrm{E}\right)$ : Signification dans le contéxte géodynamique du Mer Rouge, $C$. $R$. Acad. Sci. Paris, 300(16), 811-817.

Meneisy, M. Y. (1990), Vulcanicity, in The Geology of Egypt, edited by R. Said, pp. 157-172, A. A. Balkema, Brookfield, Vt. 
Miller, P. M., and H. Barakat (1988), Geology of the Safaga Concession, Northern Red Sea, Egypt, Tectonophysics, 153, $123-136$

Miller, S. P., K. C. Macdonald, and P. Lonsdale (1985), Near bottom magnetic profile across the Red Sea, Mar. Geophys. Res., 7, 401-418.

Mohr, P. A. (1978), Afar, Annu. Rev. Earth Planet. Sci., 6, $145-172$.

Montentat, C., et al. (1988), Tectonic and sedimentary evolution of the Gulf of Suez and the northwestern Red Sea, Tectonophysics, 153, 161-177.

Moustafa, A. M. (1976), Block faulting in the Gulf of Suez, paper presented at 5th Exploration Seminar, Gen. Pet. Corp., Cairo, Egypt.

Moustafa, A. R. (1997), Controls on the development and evolution of transfer zones: The influence of basement structure and sedimentary thickness in the Suez rift and Red Sea, J. Struct. Geol., 19, 755-768.

Moustafa, A. R. (2002), Controls on the geometry of transfer zones in the Suez rift and northwest Red Sea: Implications for the structural geometry of rift systems, AAPG Bull., 86, 979-1002.

Nicolas, A., F. Boudier, and R. Montigny (1987), Structure of Zabargad Island and early rifting of the Red Sea, J. Geophys. Res., 92, 461-474.

Oberli, F., T. Ntaflos, M. Meier, and G. Kurat (1987), Emplacement age of the peridotites from Zabargad island (Red Sea): A zircon U-Pb isotope study, Terra Cognito, 7, 334.

Omar, G. I., and M. S. Steckler (1995), Fission track evidence on the initial rifting of the Red Sea: Two pulses, no propagation, Science, 270, 1341-1344.

Orszag-Sperber, F., G. Harwood, A. Kendall, and B. H. Purser (1998a), A review of the evaporites of the Red Sea-Gulf of Suez, in Sedimentation and Tectonics of Rift Basins: Red Sea-Gulf of Aden, edited by B. H. Purser and D. W. J. Bosence, pp. 409-426, CRC Press, Boca Raton, Fla.

Orszag-Sperber, F., B. H. Purser, M. Rioual, and J.-C. Plaziat (1998b), Post-Miocene sedimentation and rift dynamics in the southern Gulf of Suez and northern Red Sea, in Sedimentation and Tectonics of Rift Basins: Red Sea-Gulf of Aden, edited by B. H. Purser and D. W. J. Bosence, pp. 427-447, CRC Press, Boca Raton, Fla.

Pallister, J. S. (1987), Magmatic history of Red Sea rifting: Perspective from the central Saudi Arabian coastal plain, Geol. Soc. Am. Bull., 98, 400-417.

Patton, T. L., A. R. Moustafa, R. A. Nelson, and A. S. Abdine (1994), Tectonic evolution and structural setting of the Suez Rift, in Interior Rift Basins, edited by S. M. Landon, pp. 955, Am. Assoc. Petrol. Geol., Tulsa, Okla.

Pautot, G. (1983), Les fosses de la Mer Rouge: Approche geomorphologique d'un stade initial d'ouvertur oceanique realisee a l'aide du Seabeam, Oceanol. Acta, 6, 235-244.

Pautot, G., P. Guennoc, A. Coutelle, and N. Lyberis (1984), Discovery of a large brine deep in the northern Red Sea, Nature, 310, 133-136.

Pautot, G., P. Guennoc, A. Coutelle, and N. Lyberis (1986), La depression axiale du segment nord Mer Rouge (de $25^{\circ} \mathrm{N}$ a $28^{\circ} \mathrm{N}$ ): Nouvelles donnees geologiques et geophysiques obtenues au cours de la campagne TRANSMEROU 83, Bull. Soc. Geol. Fr., 8, 381-399.

Plaziat, J.-C., F. Baltzer, A. Choukri, O. Conchon, P. Freytet, F. Orszag-Sperber, A. Raguideay, and J.-L. Reyss (1998a), Quaternary marine and continental sedimentation in the northern Red Sea and Gulf of Suez (Egyptian Coast): Influences of rift tectonics, climatic changes and sea-level fluctuations, in Sedimentation and Tectonics of Rift Basins: Red
Sea-Gulf of Aden, edited by B. H. Purser and D. W. J. Bosence, pp. 211-222, CRC Press, Boca Raton, Fla.

Plaziat, J.-C., C. Montentat, P. Barrier, M.-C. Janin, F. OrszagSperber, and E. R. Philobbos (1998b), Stratigraphy of the Egyptian syn-rift deposits: Correlations between axial and peripheral sequences in the northwestern Red Sea and Gulf of Suez and their relations with tectonics and eustacy, in Sedimentation and Tectonics of Rift Basins: Red Sea-Gulf of Aden, edited by B. H. Purser and D. W. J. Bosence, pp. 211-222, CRC Press, Boca Raton, Fla.

Purser, B. H., and H. Hötzl (1988), The sedimentary evolution of the Red Sea rift: A comparison of the northwest (Egyptian) and northeast (Saudi Arabian) margins, Tectonophysics, 153, 193-208

Purser, B. H., E. R. Philobbos, and M. Soliman (1990), Sedimentation and rifting in the NW parts of the Red Sea: A review, Bull. Soc. Geol. Fr., 6, 371-384.

Richards, M. A., R. A. Duncan, and V. Courtillot (1989), Flood basalts and hot-spot tracks: Plume heads and tails, Science, 246, 103-107.

Richter, H., J. Makris, and R. Rihm (1991), Geophysical observations offshore Saudi Arabia: Seismic and magnetic measurements, Tectonophysics, 198, 297-310.

Rihm, R., and C. H. Henke (1998), Geophysical studies on early tectonic controls on Red Sea rifting, opening and segmentation, in Sedimentation and Tectonics of Rift Basins: Red Sea-Gulf of Aden, edited by B. H. Purser and D. W. J. Bosence, pp. 29-49, CRC Press, Boca Raton, Fla.

Rihm, R., J. Makris, and L. Möller (1991), Seismic surveys in the northern Red Sea: Asymmetric crustal structure, Tectonophysics, 198, 279-295.

Roeser, H. A. (1975), A detailed magnetic survey of the southern Red Sea, Geol. Jahrb., 13, 131-153.

Sandwell, D. T., and W. H. F. Smith (1997), Marine gravity anomaly from Geosat and ERS1 satellite altimetry, J. Geophys. Res., 102, 10,039-10,054.

Sandwell, D. T., and W. H. F. Smith (1999), Marine gravity anomalies from satellite altimetry, Version 9.2, Univ. of Calif. San Diego, San Diego. (Available anonymously at ftp:// baltica.ucsd.edu)

Searle, R. C., and D. A. Ross (1975), A geophysical study of the Red Sea axial trough between $20.5^{\circ}$ and $22^{\circ} \mathrm{N}$, Geophys. J. R. Astron. Soc., 43, 555-572.

Sebai, A., V. Zumbo, G. Feraud, H. Bertrand, A. G. Hussain, and R. Campredon (1991), ${ }^{40} \mathrm{Ar} /{ }^{39} \mathrm{Ar}$ dating of alkaline and tholeiitic magmatism of Saudi Arabia related to the early Red Sea rifting, Earth Planet. Sci. Lett., 104, 473-487.

Shipboard Scientific Party (1974), Site 226, Initial Rep. Deep Sea Drill. Proj., 24, 595-600.

Shukri, N. M. (1944), Geology of the Brothers Islets, Bull. Egypt. Fac. Sci., 75, 175-196.

Smith, W. H. F., and D. T. Sandwell (1997), Global sea floor topography from satellite altimetry and ship depth soundings, Science, 277, 1956-1962.

Smith, W. H. F., and P. Wessel (1990), Gridding with continuous curvature splines in tension, Geophysics, 55, 293-305.

Steckler, M. S., and U. S. ten Brink (1986), Lithospheric strength variations as a control on new plate boundaries: Examples from the northern Red Sea region, Earth. Planet. Sci. Lett., 79, 120-132.

Steckler, M. S., F. Berthelot, N. Lyberis, and X. LePichon (1988), Subsidence in the Gulf of Suez: Implications for rifting and plate kinematics, Tectonophysics, 153, 249270.

Steinitz, G., Y. Bartov, and J. C. Hunziker (1978), K-Ar age determinations of some Miocene-Pliocene basalts in Israel: 
Their significance to the tectonics of the Rift Valley, Geol. Mag., 115, 329-340.

Stern, R. J., and C. E. Hedge (1985), Geochronologic and isotopic constraints on Late Precambrian crustal evolution in the Eastern Desert of Egypt, Am. J. Sci., 285, 97-127.

Stern, R. J., D. Gottfried, and C. E. Hedge (1984), Late Precambrian rifting and crustal evolution in the Northeastern Desert of Egypt, Geology, 12, 168-172.

Taviani, M., E. Bonatti, P. Colantoni, and P. Rossi (1984), Tectonically uplifted crustal blocks in the northern Red Sea: Data from the Brothers islets, Mem. Soc. Geol. Ital., 27, 47-50.

Villa, I. M. (1990), ${ }^{40} \mathrm{Ar} /{ }^{39} \mathrm{Ar}$ dating of amphiboles from Zabargad Island is precluded by interaction with fluids, Tectonophysics, 180, 369-373.

Wessel, P., and W. H. F. Smith (1998), New improved version of Generic Mapping Tools released, Eos Trans. AGU, 79, 579.
Whitmarsh, R. B., O. E. Wesser, and D. A. Ross (1974), Initial Reports of the Deep Sea Drilling Project, vol. 23, 1180 pp., U.S. Govt. Print. Off., Washington, D. C.

Younes, A. I., and K. McClay (2002), Development of accommodation zones in the Gulf of Suez-Red Sea rift, Egypt, AAPG Bull., 86, 1003-1026.

Zierenberg, R. A., and W. C. Shanks (1988), Isotopic studies of epigenetic features in metaliferous sediment, Atlantis II Deep, Red Sea, Can. Mineral., 26, 737-753.

Zumbo, V., G. Feraud, H. Bertrand, and G. Chazot (1995a), ${ }^{40} \mathrm{Ar} /{ }^{39} \mathrm{Ar}$ chronology of tertiary magmatic activity in southern Yemen during the early Red Sea - Aden rifting, J. Volcanol. Geotherm. Res., 65, 265-279.

Zumbo, V., G. Feraud, P. Vellutini, P. Piguet, and J. Vincent (1995b), First ${ }^{40} \mathrm{Ar} /{ }^{39} \mathrm{Ar}$ dating on early Pliocene to PlioPleistocene magmatic events of the Afar- Republic of Djibouti, J. Volcanol. Geotherm. Res., 65, 281-295. 